\title{
Spectral, thermal, antimicrobial studies for silver(I) complexes of pyrazolone derivatives
}

\author{
Soha F. Mohamed ${ }^{1}$, Wesam S. Shehab', Aboubakr M. Abdullah², Mostafa H. Sliem² \\ and Walaa H. El-Shwiniy ${ }^{1,3^{*}}$ (D)
}

\begin{abstract}
Background: Synthesize new complexes of Ag(I) to enhance efficacy or stability and also, pharmacological activities on the operation of pyrazolone's biological properties.

Results: Efficient and high yielding pathways starting from the versatile and readily available 3-methyl-1-phenyl5-pyrazolone by Knoevenagel condensation of a sequence of 4-arylidene-3-methyl-1-phenyl-5-pyrazolone derivatives (2a-c) have been formed by the reaction of various substituted aromatic aldehydes Used as ligands to synthesize $\mathrm{Ag}(\mathrm{I})$ chelates. Synthesized compounds and their complexes have been characterized by elemental analysis, magnetic and spectroscopic methods (IR, ${ }^{13} \mathrm{C},{ }^{1} \mathrm{HNMR}$, mass) and thermal analysis. The spectrophotometric determinations suggest distorted octaedral geometry for all complexes. Both ligands and their metal complexes have also been tested for their antibacterial and antifungal efficacy.
\end{abstract}

Conclusions: Newly synthesized compounds have shown potent antimicrobial activity. The results showed that the complex 's high activity was higher than its free ligands, and that $\mathrm{Ag}(\mathrm{I})-\mathrm{L}_{3}$ had the highest activity.

Keywords: Pyrazolones, Ag(i) complexes, Knoevenagel condensation, Antimicrobial activity

\section{Introduction}

Pyrazolone chemistry began in 1883 when Ludwig Knorr first reacted to phenyl hydrazine with aceto-acetate ester. As pyrazolones were discovered as binding components for azo dyes in the late 1800s, they rapidly increased in importance. Today, pyrazolon is still an significant trade precursor to dyes and pharmaceuticals. Pyrazolone is a biologically important scaffold associated with different pharmacological activities such as antimicrobials [1-5], anti-inflammatory [6], analgesic [7], antidepressant [8], anticonvulsant [9], antidiabetic [10], antihyperlipidemic $[11,12]$, antiviral $[13,14]$, anti-tuberculosis [15,

\footnotetext{
*Correspondence: bakr@qu.edu.qa; abubakr_2@yahoo.com; whelmy@ub.edu.sa

${ }^{1}$ Department of Chemistry, Faculty of Science, Zagazig University, Zagazig 44519, Egypt

${ }^{2}$ Center for Advanced Materials, Qatar University, P.O. Box 2713, Doha, Qatar

Full list of author information is available at the end of the article
}

16], antioxidant $[17,18]$ and anticancer $[19,20]$. For several years, the preparation of pyrazolone and its derivatives has attracted significant attention from organic and medicinal chemists, as they belong to a class of compounds with promising results in medicinal chemistry. The heterocycles condensed to the pyrazole ring are an important source of bioactive molecules [21, 22]. Compounds containing both pyrazole and other essential heterocyclic active structural units usually demonstrate more remarkable biological activity. A number of condensed pyrazole derivatives have been reported as four-fold antibacterial agents against Gram-positive and Gram-negative bacteria compared to general pyrazole compounds [23, 24]. A digit of antimicrobial active silver(I) complexes have the capacity to disrupt microbial transpiration as well as block tyrosinase synthesis and are extremely cytotoxic to cancer cells [24]. Massive attention in silver ions $(\mathrm{Ag}(\mathrm{I}))$ as a broad spectrum antimicrobial has upped the size and importance of in vitro

(c) The Author(s) 2020. This article is licensed under a Creative Commons Attribution 4.0 International License, which permits use, sharing, adaptation, distribution and reproduction in any medium or format, as long as you give appropriate credit to the original author(s) and the source, provide a link to the Creative Commons licence, and indicate if changes were made. The images or other third party material in this article are included in the article's Creative Commons licence, unless indicated otherwise in a credit line to the material. If material is not included in the article's Creative Commons licence and your intended use is not permitted by statutory regulation or exceeds the permitted use, you will need to obtain permission directly from the copyright holder. To view a copy of this licence, visit http://creativeco mmons.org/licenses/by/4.0/. The Creative Commons Public Domain Dedication waiver (http://creativecommons.org/publicdomain/ zero/1.0/) applies to the data made available in this article, unless otherwise stated in a credit line to the data. 
biocompatibility research [25]. Silver ions are toxic to many bacteria, viruses, algae and fungi. Silver-based medicines have been widely used for this task for decades [26]. The objective of this study is to display the synthesis and characterization of three $\mathrm{Ag}(\mathrm{I})$ pyrazolone complexes in an attempt to verify the mode of coordination and the biological properties of the final complexes.

\section{Results and discussion}

\section{Synthesis and formulation}

A sequence of derivatives of 4-arylidene-3-methyl-1-phenyl-5-pyrazolone (4-(4-dimethylamino benzylidene)3-methyl-1-phenyl-1H-pyrazol-5 $(4 H)$-one (2a) $\mathrm{L}_{1}$, 4-(4-Thiophene)-3-methyl-1-phenyl-1Hpyrazol-5(4H)one (2b) $\mathrm{L}_{2}$, 4-(4-methoxy benzylidene)-3-methyl1-phenyl-1Hpyrazol-5(4H)-one $\left.(2 \mathrm{c}) \mathrm{L}_{3}\right)$ is synthesized by condensing 3-methyl-1-phenyl-5-pyrazolone with substituted aromatic aldehydes as shown in Scheme 1 [27]. Three $\operatorname{Ag}(\mathrm{I})$ complexes have been prepared with the $\mathrm{L}_{1}$, $\mathrm{L}_{2}, \mathrm{~L}_{3}$ ligands as shown in Scheme 2. Based on physicochemical and spectral data (IR and ${ }^{1} \mathrm{HNMR}$ ), structure of the synthesized compounds (2a-c, Ag(I) complexes) has been evaluated.

\section{Infrared spectra}

$\mathrm{KBr}$ disks registered mid-infrared spectra of $\mathrm{L}_{1}, \mathrm{~L}_{2}, \mathrm{~L}_{3}$ and their metal complexes. As expected, with changes in band intensities and wave numbers, the absorption bands characteristic of $\mathrm{L}_{1}, \mathrm{~L}_{2}, \mathrm{~L}_{3}$ acting as a monodentate unit are observed in the complexes. The proposed structures of the complexes must be considered prior to determining the assignments of the infrared spectra. Here, $\mathrm{Ag}(\mathrm{I})$ ion interacts with these monodentate ligands forming monomeric structure complexes in which the $\operatorname{Ag}(\mathrm{I})$ ion is four coordinated (Scheme 2) [27-30].

The complexes of three ligands with $\mathrm{Ag}(\mathrm{I})$ contain only one plane of symmetry and therefore the complexes that belong to $C_{S}$ symmetry and show 159 vibrational fundamentals, and all vibrations are distributed between movements of the types $A^{\prime}$ and $A_{1}{ }^{\prime \prime}$, all of which are monodegenrate, infra-red and Raman active. The free ligand infrared spectrum shows bands at 1496, 1508 and $1550 \mathrm{~cm}^{-1}$ due to the stretching vibration of hydrazono $(\mathrm{C}=\mathrm{N})$ groups [31]. Comparing the $\mathrm{Ag}(\mathrm{I})$ IR spectrum with the free ligand spectrum, the transfer of $(C=N)$ groups to lower frequency values $(1512,1515,1523$ and $\left.1527 \mathrm{~cm}^{-1}\right)$ and the change in strength of $(\mathrm{C}=\mathrm{N})$ from

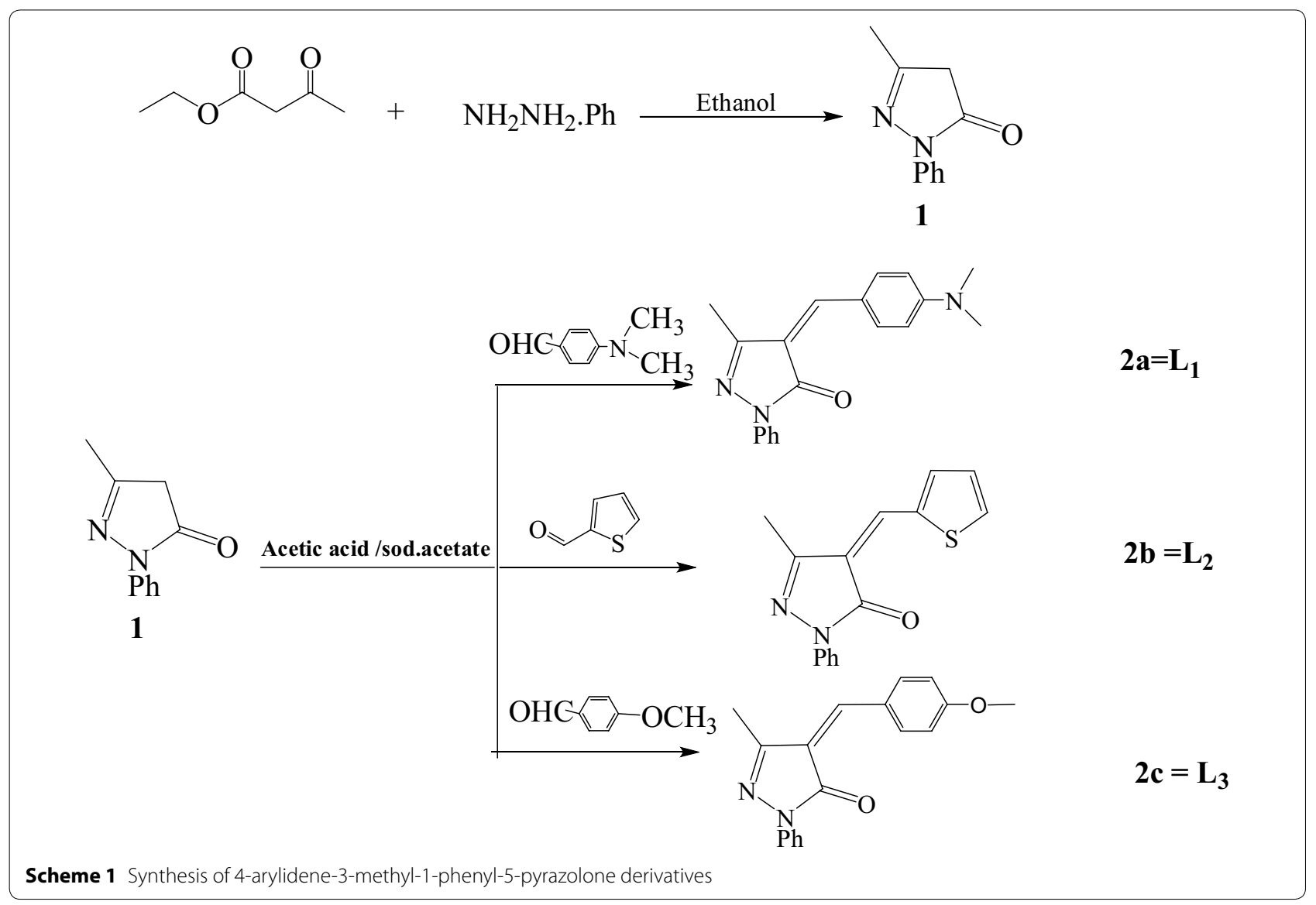




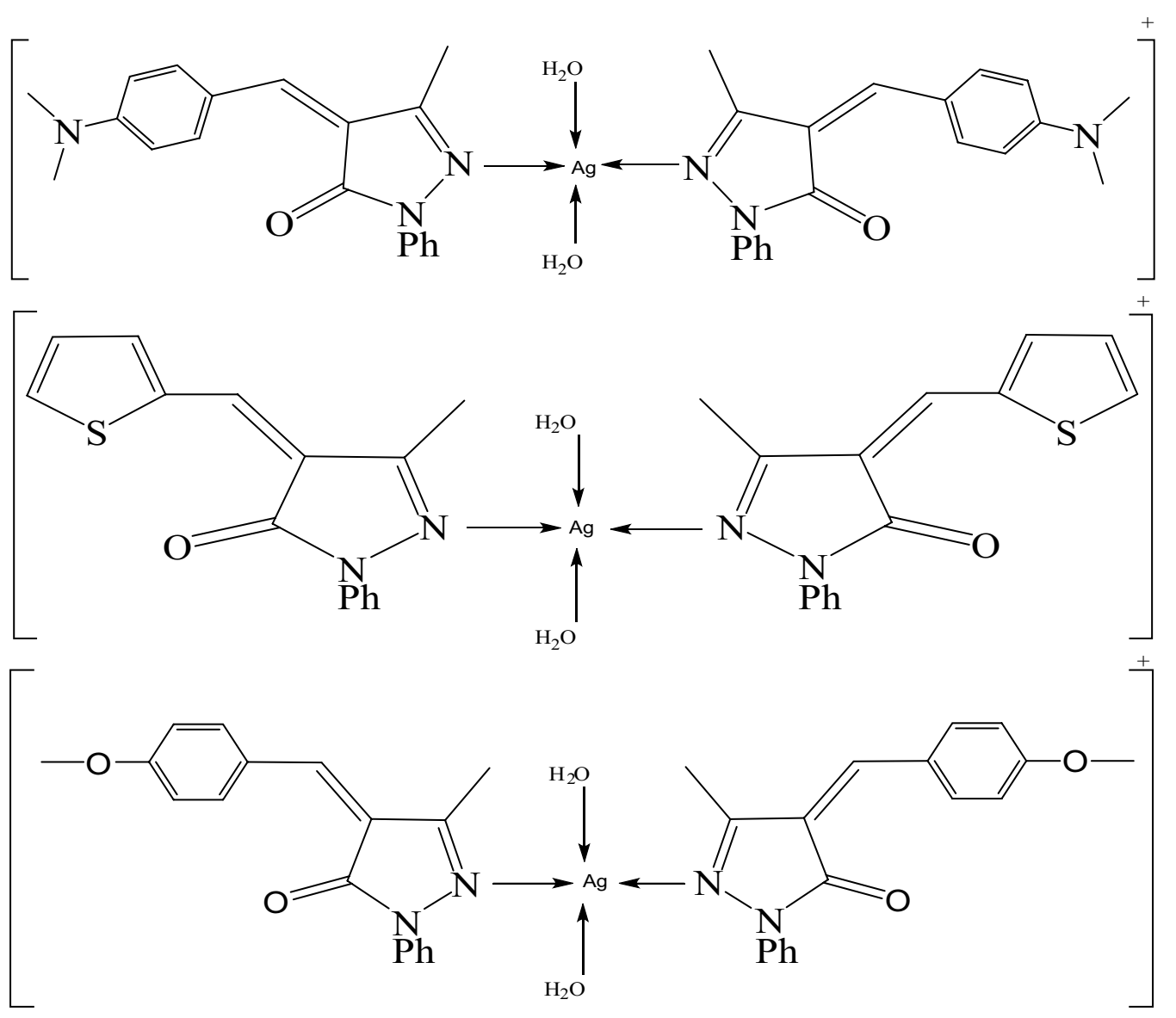

Scheme 2 The coordinationn mode of Ag (I) with three ligand

medium to strong (Fig. 1 and Table 1) which confirms that the ligand molecule coordinated with metal ions through the hydrazon nitrogen atom [31]. A medium wide band for the $\mathrm{H}_{2} \mathrm{O}$ stretching vibrations of coordinated water molecules at 3379,3364 , and $3364 \mathrm{~cm}^{-1}$ [31];The stretching vibrations $v(\mathrm{C}-\mathrm{H})$ of phenyl groups and $-\mathrm{CH}_{3}$ units in these complexes are assigned as a number of bands in the region 3066-3100 $\mathrm{cm}^{-1}$ [11, 12]. The $v(C=\mathrm{O})$ vibration appears in the region of $1666-1685 \mathrm{~cm}^{-1}$. The spectra of the isolated solid complexes revealed a number of new bands of different intensities for $v(\mathrm{M}-\mathrm{N})$. The $v(\mathrm{Ag}-\mathrm{N})$ bands observed at 813, $837 \mathrm{~cm}^{-1}$ for $\mathrm{Ag}(\mathrm{I})-\mathrm{L}_{1}$, at $748,794 \mathrm{~cm}^{-1}$ for $\mathrm{Ag}(\mathrm{I})-\mathrm{L}_{2}$ and at $759,779 \mathrm{~cm}^{-1}$ for $\mathrm{Ag}(\mathrm{I})-\mathrm{L}_{3}$ (Table 1) which are absent in the spectrum of free three ligands [30-32]. The coordinating water in the three complexes are characterized by the appearance of $v(\mathrm{Ag}-\mathrm{O})$ at $577,515,544 \mathrm{~cm}^{-1}$. Also the stretching vibrations at $813,792,779 \mathrm{~cm}^{-1}$ assigned to $v\left(\mathrm{Ag} \mathrm{OH}_{2}\right)$, sponsored coordinating water participation [32]. The suggested structural formulas are defined in Scheme 2 on the basis of the IR tests.

\section{UV-Visible Spectra}

The application of ultraviolet spectroscopy is more general and can be useful for all chelate structural determinations as they are all absorbed in this region [33]. Electronic absorption spectra confirmed the development of metal ligand complexes. Electronic absorption spectra $L_{1}$ for $\operatorname{Ag}(\mathrm{I}), \mathrm{L}_{2}$ for $\operatorname{Ag}(\mathrm{I})$ and $\mathrm{L}_{3}$ for $\operatorname{Ag}(\mathrm{I})$. Complexes within the spectrum of wavelengths between 200 and $800 \mathrm{~nm}$ are described in Additional file 1: Table S1 and Fig. 2. The free three-ligand UV spectrum $\left(\mathrm{L}_{1}, \mathrm{~L}_{2}\right.$ and $\mathrm{L}_{3}$ ) displays bands at 281, 297 and $297 \mathrm{~nm}$ that are assigned respectively to $\pi-\pi$. And displays bands allocated to $n-\pi *$ transitions at $330 \mathrm{~nm}$. The modification of the reflectance band to higher (bathochromic shift) and lower values (hypochromic shift) and the appearance of new bands for complexes has resulted in the release of three ligands' complex actions towards metal ions. Complexes also present bands within the range $410-480 \mathrm{~nm}$ which can be due to the transition of ligand-metal charges for three ligands [34, 36]. The molar absorptivity $(\varepsilon)$ values of the prepared metal 


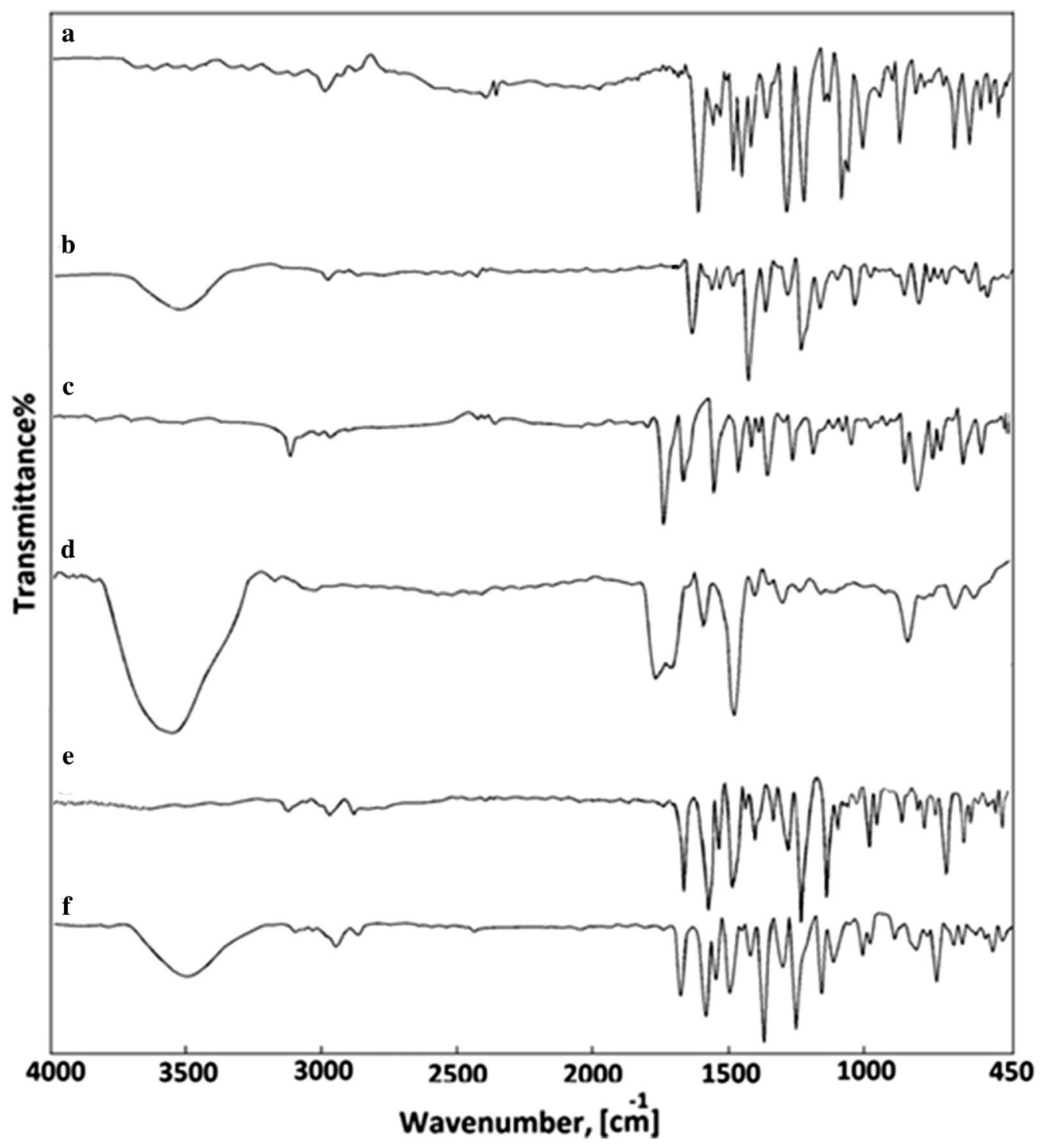

Fig. 1 Infrared spectra for $\mathbf{a} \mathrm{L}_{1}, \mathbf{b}\left[\mathrm{Ag}\left(\mathrm{L}_{1}\right)_{2}\left(\mathrm{H}_{2} \mathrm{O}\right)_{2}\right] \mathrm{NO}_{3}, \mathbf{c} \mathrm{L}_{2}, \mathbf{d}\left[\mathrm{Ag}\left(\mathrm{L}_{2}\right)_{2}\left(\mathrm{H}_{2} \mathrm{O}\right)_{2}\right] \mathrm{NO}_{3} \cdot \mathrm{H}_{2} \mathrm{O}, \mathbf{e} \mathrm{L}_{3}$ and $\mathbf{f}\left[\mathrm{Ag}\left(\mathrm{L}_{3}\right)_{2}\left(\mathrm{H}_{2} \mathrm{O}\right)_{2}\right] \mathrm{NO}_{3}$

complexes under investigation were determined (Additional file 1: Table S1) using the relation: $\mathrm{A}=\varepsilon \mathrm{cl}$, where, $\mathrm{A}=$ absorbance, $\mathrm{c}=1.0 \times 10^{-3} \mathrm{M}, \mathrm{l}=$ length of cell $(1 \mathrm{~cm})$ [22]. The values of 10Dq (difference between $t_{2 g}$ and $e_{g}$ ) for the complexes were calculated by using the following Eq. $10 \mathrm{Dq}=\mathrm{E}=\mathrm{hcv}^{-}$where $\mathrm{E}=$ energy, $\mathrm{h}=$ blank constant $=6.626 \times 10^{-34} \mathrm{~J} . \mathrm{sec}, \mathrm{c}=3 \times 10^{10} \mathrm{~cm} / \mathrm{sec}, v^{-}=$wave number $\mathrm{cm}^{-1}$ the data listed in Additional file 1: Table S1.

\section{The ${ }^{1}$ H NMR spectra}

Suggested structure of the isolated $\mathrm{Ag}(\mathrm{I})$ complexes confirm about the efficiency of ${ }^{1} \mathrm{H}$ NMR spectra. Compared to the one of their complexes (Additional file 1: Table S2), the ${ }^{1} \mathrm{H}$ NMR spectra of new free three ligands in DMSO$\mathrm{d}_{6}$. The ${ }^{1} \mathrm{H}$ NMR spectra of $\mathrm{L}_{1}$ and its metal complex shown in (Fig. 3a, b), the proton of $(=\mathrm{CH}-\mathrm{Ar})$ group observed in $\delta: 9.66 \mathrm{ppm}$ and the protons of aromatic ring of (s, 9H, Aromatic-H) observed at $\delta: 7.14-7.97 \mathrm{ppm}$ also the values of protons of $-\mathrm{CH}$ aliphatic observed in the range $\delta: 3.03-3.33 \mathrm{ppm}\left(\mathrm{s}, 6 \mathrm{H},-\mathrm{N}\left(\mathrm{CH}_{3}\right)_{2}\right)$, the proton of $\left(\mathrm{s}, 3 \mathrm{H},-\mathrm{CH}_{3}\right)$ group observed in $\delta 2.28 \mathrm{ppm}$, no major differences were observed as opposed to the $\mathrm{Ag}(\mathrm{I})$ complex except that the signal is observed in $3.46 \mathrm{ppm}$ due to $\mathrm{H}_{2} \mathrm{O}$ molecules [36]. This supports the hypothesis that $\mathrm{L}_{1}$ interacts as a monodentate ligand bound to the $\mathrm{Ag}(\mathrm{I})$ ion through the hydrazono nitrogen group. [37]. 
Table 1 Infrared frequencies $\left(\mathrm{cm}^{-1}\right)^{a}$ and tentative assignments ${ }^{b}$ for $(A) L_{1},(B)\left[A g\left(L_{1}\right)_{2}\left(H_{2} O\right)_{2}\right] N_{3},(C), L_{2}$ (D) $\left[\mathrm{Ag}\left(\mathrm{L}_{2}\right)_{2}\left(\mathrm{H}_{2} \mathrm{O}\right)_{2}\right] \mathrm{NO}_{3} \cdot \mathrm{H}_{2} \mathrm{O},(\mathrm{E}) \mathrm{L}_{3}$ and $(\mathrm{F})\left[\mathrm{Ag}\left(\mathrm{L}_{3}\right)_{2}\left(\mathrm{H}_{2} \mathrm{O}\right)_{2}\right] \mathrm{NO}_{3}$

\begin{tabular}{|c|c|c|c|c|c|c|}
\hline A & B & $\mathrm{C}$ & D & $\mathrm{E}$ & $F$ & Assignments \\
\hline- & $3379_{m, b r}$ & - & $3364_{m, b r}$ & - & $3364_{m, b r}$ & $v(\mathrm{O}-\mathrm{H})$; coordinate $\mathrm{H}_{2} \mathrm{O}$ \\
\hline $3100_{w}$ & $3100_{w}$ & $3066_{w}$ & $3100_{w}$ & 3099 & 3100 & $\mathrm{v}(\mathrm{C}-\mathrm{H})$; aromatic \\
\hline 2900 & 2900 & 2890 & 2885 & 2901 & 2900 & $v(C-H)$; aliphatic \\
\hline $1670_{\mathrm{ms}}$ & $1666_{\mathrm{m}}$ & $1681_{s}$ & $1685_{s, s h}$ & $1678_{m}$ & $1678_{m}$ & $v(C=O)$ \\
\hline $\begin{array}{l}1550_{\mathrm{s}} \\
1400_{\mathrm{m}}\end{array}$ & $\begin{array}{l}1523_{m} \\
1410_{s}\end{array}$ & $1496_{m} 1408_{m}$ & $\begin{array}{l}1527 \mathrm{~m} \\
1381\end{array}$ & $\begin{array}{l}1508_{s} \\
1427_{v w}\end{array}$ & $\begin{array}{l}1520_{s} \\
1415\end{array}$ & $\begin{array}{l}v(C=N) \\
v(C=C)\end{array}$ \\
\hline $\begin{array}{l}1319_{\mathrm{s}} \\
-\end{array}$ & $\begin{array}{l}1319_{s} \\
1188_{s}\end{array}$ & $\begin{array}{l}1300_{s} \\
-\end{array}$ & $\begin{array}{l}1311_{w} \\
1165_{m}\end{array}$ & $\begin{array}{l}1311_{\text {sh }} \\
-\end{array}$ & $\begin{array}{l}1311_{m} \\
1172_{s}\end{array}$ & $\begin{array}{l}\delta_{b}\left(-\mathrm{CH}_{2}\right) \\
v\left(\mathrm{NO}_{3}{ }^{-1}\right)\end{array}$ \\
\hline $\begin{array}{l}1122_{s} \\
1018_{w} \\
-\end{array}$ & $\begin{array}{l}1122_{s} \\
1018_{w} \\
-\end{array}$ & $\begin{array}{l}1130_{m} \\
- \\
1056_{w}\end{array}$ & $\begin{array}{l}1104_{v w} \\
- \\
1099_{\text {sh }}\end{array}$ & $\begin{array}{l}1110_{w} \\
- \\
-\end{array}$ & $\begin{array}{l}1130_{m} \\
- \\
-\end{array}$ & $\begin{array}{l}v(C-C) \\
v(C-N) \\
v(C=S)\end{array}$ \\
\hline $\begin{array}{l}954_{w} \\
943_{v w}\end{array}$ & $\begin{array}{l}995_{w} \\
995_{m}\end{array}$ & $\begin{array}{l}991_{\mathrm{s}} \\
921_{\mathrm{w}}\end{array}$ & $\begin{array}{l}941_{v w} \\
910_{v w}\end{array}$ & $\begin{array}{l}988_{w} \\
938_{s}\end{array}$ & $\begin{array}{l}985_{w} \\
965_{s h}\end{array}$ & - $\mathrm{CH}$-bend; phenyl \\
\hline- & $813_{m}$ & - & $792 m$ & - & $779_{\mathrm{m}}$ & $v\left(\mathrm{Ag} \leftarrow \mathrm{OH}_{2}\right)$ \\
\hline- & $577 w$ & - & $515 w$ & - & $544 w$ & $v(\mathrm{Ag}-\mathrm{O})$ \\
\hline- & $524 w$ & - & 498w & - & $488 w$ & $v(\mathrm{Ag}-\mathrm{N})$ \\
\hline
\end{tabular}

${ }^{a} \mathrm{~s}=$ strong, $\mathrm{w}=$ weak, $\mathrm{sh}=$ shoulder, $\mathrm{v}=$ very, $\mathrm{br}=\mathrm{broad}^{\mathrm{b}} \mathrm{v}=$ stretching and $\delta=$ bending

The ${ }^{1} \mathrm{H}$ NMR spectra of $\mathrm{L}_{2}$ and its $\mathrm{Ag}(\mathrm{I})$ complex shown in (Fig. 3c, d), the proton of ( $=\mathrm{CH}-\mathrm{Ar})$ group observed in $\delta: 8.25 \mathrm{ppm}$ and, the protons of aromatic ring of (s, $8 \mathrm{H}$, Aromatic-H) observed at $\delta: 7.39-7.91 \mathrm{ppm}[38]$. The proton of $\left(\mathrm{s}, 3 \mathrm{H},-\mathrm{CH}_{3}\right)$ group observed in $\delta 2.30 \mathrm{ppm}$, simple differences are shown in comparison to the metal complex and the signal is observed in $\pi: 3.47 \mathrm{ppm}$ due to $\mathrm{H}_{2} \mathrm{O}$ molecules. This reinforces the hypothesis that $\mathrm{L}_{2}$ reacts via the hydrazono nitrogen group as a monodentate ligand bound to the $\mathrm{Ag}(\mathrm{I})$ ion. The ${ }^{1} \mathrm{H}$ NMR spectra of $\mathrm{L}_{3}$ and its $\operatorname{Ag}(\mathrm{I})$ complex shown in (Fig. 3 (E, F)), the proton of $(=\mathrm{CH}-\mathrm{Ar})$ group observed in $\delta: 8.71 \mathrm{ppm}$ and the protons of aromatic ring of (s, 9H, Aromatic- $\mathrm{H})$ observed at $\delta: 7.18-7.46 \mathrm{ppm}$ also the values of protons of - $\mathrm{CH}$ aliphatic observed in the range $\delta: 3.31 \mathrm{ppm}(\mathrm{s}, 3 \mathrm{H}$, $\left.-\mathrm{O}-\mathrm{CH}_{3}\right)$, the proton of $\left(\mathrm{s}, 3 \mathrm{H},-\mathrm{CH}_{3}\right)$ group observed in $\delta 2.33 \mathrm{ppm}$, no major variations were noticed as opposed to the $\operatorname{Ag}(\mathrm{I})$ series. This supports the assumption that $\mathrm{L}_{3}$ reacts as a monodentate ligand bound to the $\mathrm{Ag}(\mathrm{I})$ ion via the hydrazone nitrogen group.

\section{Thermal studies}

The thermal degradation of ligand $\left(\mathrm{L}_{1}\right)$ began at $190{ }^{\circ} \mathrm{C}$ and decay occurs at various temperatures at $310,544{ }^{\circ} \mathrm{C}$ at one stage (Additional file 1: Fig. S1a). This step is accompanied by a net weight loss of 92.36 percent, equivalent to the predicted 92.07 percent. Corresponding to the loss of $8 \mathrm{C}_{2} \mathrm{H}_{2}+\mathrm{NH}_{3}+\mathrm{CO}+\mathrm{N}_{2}$ molecule and $95.65 \mathrm{KJ} \mathrm{mol}^{-1}$ (endothermic) activation energy. The residue value decomposes at a height of $800{ }^{\circ} \mathrm{C}$ and the actual losing weight at this point is 7.64 percent, close to the estimated 7.86 percent equal to $2 \mathrm{C}$. The $\left[\mathrm{Ag}\left(\mathrm{L}_{1}\right)_{2}\left(\mathrm{H}_{2} \mathrm{O}\right)_{2}\right] \mathrm{NO}_{3}$ complex decomposed in two steps (Additional file 1: Fig. S1b), The first one begins at a limit of $189^{\circ} \mathrm{C}$ and is followed by a 33.378 percent weight loss leading to a $9 \mathrm{C}_{2} \mathrm{H}_{2}+2 \mathrm{H}_{2} \mathrm{O}$ loss similar to the estimated value of 33.062 percent with an activation energy of $34.37 \mathrm{~kJ} \mathrm{~mol}^{-1}$. The second step occurs at 366 and $562{ }^{\circ} \mathrm{C}$ followed by a weight loss of 52.79 percent; equivalent to a value of $8 \mathrm{C}_{2} \mathrm{H}_{2}+4 \mathrm{HCN}+\mathrm{NO}+2 \mathrm{~N}_{2} \mathrm{O}$, potentially similar to the measured value of 53.798 percent. The residue value proceeds at $931^{\circ} \mathrm{C}$ and the overall weight loss from this stage is 13.474 percent, referring to $\mathrm{Ag}$, similar to the 13.14 percent estimated value (Table 2 ).

The ligand $\left(\mathrm{L}_{2}\right)$ degradates at $273,475{ }^{\circ} \mathrm{C}$. This stage is followed by a complete loss of weight of 86.70 percent, close to 86.56 percent of the estimated value (Additional file 1: Fig. S1c). Equivalent to $6 \mathrm{C}_{2} \mathrm{H}_{2}+\mathrm{SO}+\mathrm{N}_{2}$ loss and $31.93 \mathrm{~kJ} \mathrm{~mol}^{-1}$ (endothermic) activation energy. Decomposition of the residual value occurs at $771{ }^{\circ} \mathrm{C}$ and the real weight loss from this stage is 13.30 percent, similar to the estimated value of 13.43 percent corresponding to $3 \mathrm{C}$. The $\left[\mathrm{Ag}\left(\mathrm{L}_{2}\right)_{2}\left(\mathrm{H}_{2} \mathrm{O}\right)_{2}\right]$ $\mathrm{NO}_{3} \cdot \mathrm{H}_{2} \mathrm{O}$ complex decomposes at two levels of decay (Additional file 1: Fig. S1d), the first phase occurs at $99{ }^{\circ} \mathrm{C}$ and is followed by a weight loss of 2.08 per cent relating to the removal of $\mathrm{H}_{2} \mathrm{O}$, activation energy of $79.28 \mathrm{~kJ} \mathrm{~mol}^{-1}$. The second step of decomposition occurs at temperature is 203, 528 and is accompanied by a weight loss of $75.90 \%$; corresponding to the value of $10 \mathrm{C}_{2} \mathrm{H}_{2}+4 \mathrm{HCN}+2 \mathrm{H}_{2} \mathrm{O}+\mathrm{NO}_{2}+\mathrm{SO}+\mathrm{SO}_{2}$ theoretically, close to the calculated value $76.404 \%$. 

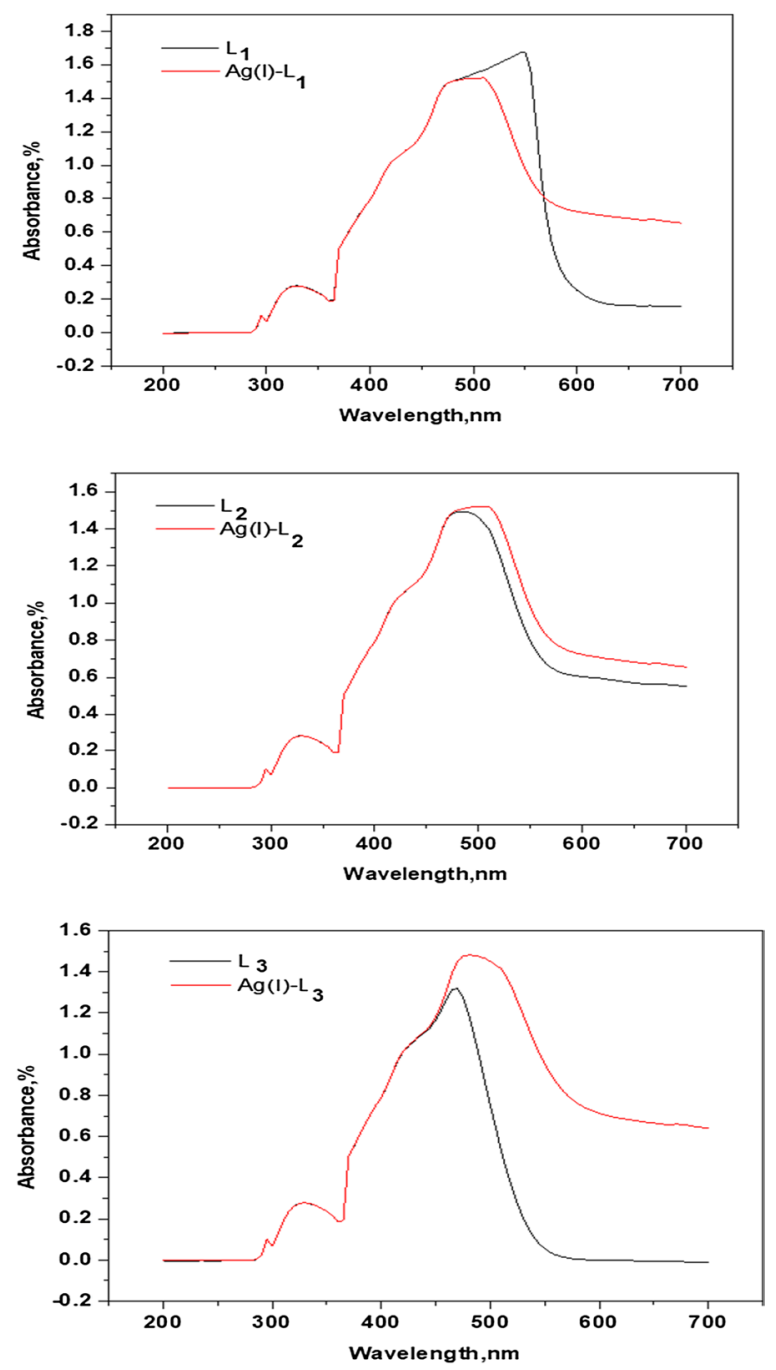

Fig. 2 Electronic absorption spectra for $\mathrm{L}_{1},\left[\mathrm{Ag}\left(\mathrm{L}_{1}\right)_{2}\left(\mathrm{H}_{2} \mathrm{O}\right)_{2}\right] \mathrm{NO}_{3}, \mathrm{~L}_{2}$, $\left[\mathrm{Ag}\left(\mathrm{L}_{2}\right)_{2}\left(\mathrm{H}_{2} \mathrm{O}\right)_{2}\right] \mathrm{NO}_{3} \cdot \mathrm{H}_{2} \mathrm{O}, \mathrm{L}_{3}$ and $\left[\mathrm{Ag}\left(\mathrm{L}_{3}\right)_{2}\left(\mathrm{H}_{2} \mathrm{O}\right)_{2}\right] \mathrm{NO}_{3}$

The Residue value decomposition occurs at maximum $881{ }^{\circ} \mathrm{C}$ and the actual weight loss from this step is $23.35 \%$, corresponding to $\mathrm{Ag}+6 \mathrm{C}$, close to the calculated value $23.596 \%$.

The thermal decay of $L_{3}$ happens in two phases of degradation (Additional file 1: Fig. S1e), the first step arises at $291{ }^{\circ} \mathrm{C}$ and is followed by a weight loss of 70.55 percent leading to a loss of $8 \mathrm{C}_{2} \mathrm{H}_{2}$ similar to the measured value of 71.23 per cent with activation energy of $35.31 \mathrm{~kJ} \mathrm{~mol}^{-1}$. The second step occurs at $518{ }^{\circ} \mathrm{C}$ and is accompanied by a weight loss of $28.604 \%$; corresponding to the value of $2 \mathrm{CO}+\mathrm{N}_{2}$ theoretically, close to the calculated value $28.67 \%$. The $\left[\mathrm{Ag}\left(\mathrm{L}_{3}\right)_{2}\left(\mathrm{H}_{2} \mathrm{O}\right)_{2}\right] \mathrm{NO}_{3}$ degradation takes place in two stages (Additional file 1: Fig. S1f), the first occurs at $244{ }^{\circ} \mathrm{C}$ and is accompained by a weight

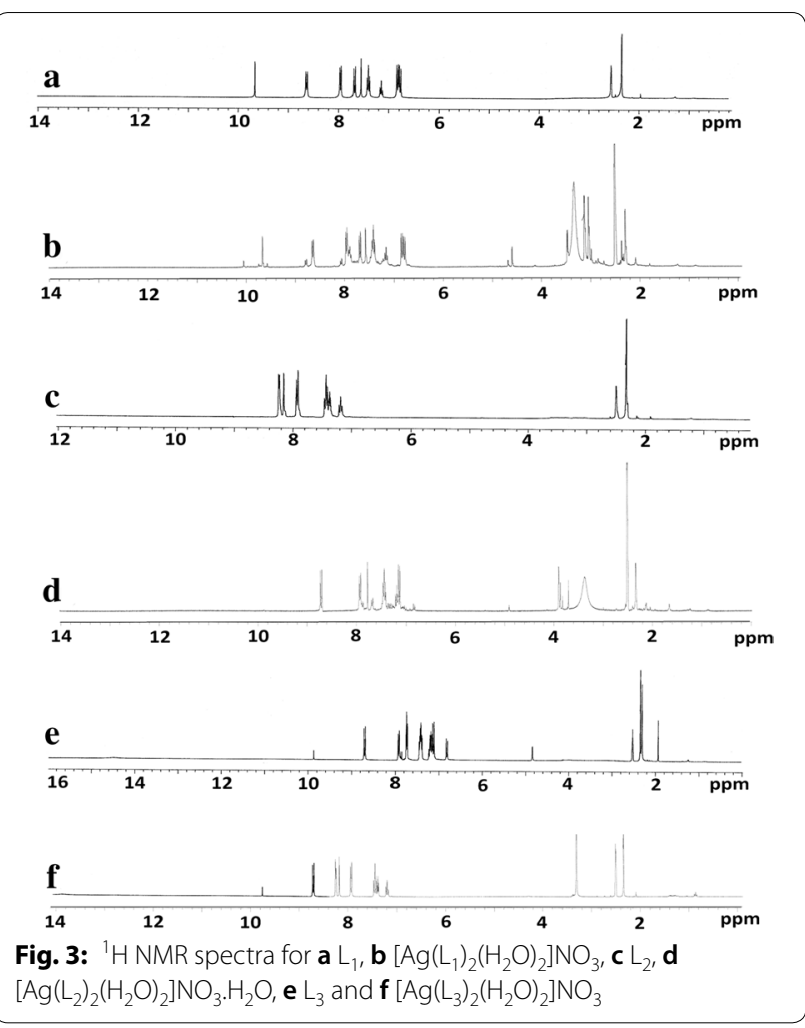

loss of $51.071 \%$ corresponding to loss of $14 \mathrm{C}_{2} \mathrm{H}_{2}+2 \mathrm{H}_{2} \mathrm{O}$ close to the calculated value $50.60 \%$ with an activation energy $15.31 \mathrm{~kJ} \mathrm{~mol}^{-1}$. The second one begins at $543{ }^{\circ} \mathrm{C}$ and is followed by a weight loss of $30.17 \%$; corresponding to $\mathrm{C}_{2} \mathrm{H}_{2}+\mathrm{CO}+2 \mathrm{HCN}+3 \mathrm{NO}_{2}$ theoretically, close to the calculated value $31.25 \%$. The Residue remains at $677{ }^{\circ} \mathrm{C}$ and the actual weight loss is $17.76 \%$, equal to $\mathrm{Ag}+3 \mathrm{C}$, close to the calculated value $18.15 \%$.

\section{Kinetic data}

The kinetic parameters (activation energy, $\mathrm{E}^{*}$, entropy, $\Delta \mathrm{S}^{*}$, enthalpy, $\Delta \mathrm{H}^{*}$, and Gibbs free energy, $\Delta \mathrm{G}^{*}$ ) have been evaluated by using the two mentioned methods in the literature $[39,40]$ and shown in Additional file 1: Fig. S2 and listed in Table 3. The correlation coefficient for Arrhenius plots of thermal degradation stages were found to be in the range $0.943-0.985$, revealing a good fit with linear function. The activation energies of decomposition were observed to be in the range 7.44$154.69 \mathrm{~kJ} \mathrm{~mol}^{-1}$. The negative values of $\Delta S^{*}$ indicate that the activation complex has a more ordered structure than the reactants or the reactions are slow. The positive $\Delta \mathrm{H}^{*}$ values postulate an endothermic nature of the formed complexes. The greater positive values of $E^{*}$ indicate that the processes involving in translational, rotational, vibrational states and a changes in mechanical potential 
Table 2 Thermogravimetric data of $L_{1}, L_{2}, L_{3}$ and their metal complexes

\begin{tabular}{|c|c|c|c|c|c|}
\hline \multirow[t]{2}{*}{ Compounds } & \multirow[t]{2}{*}{ Decomposition } & \multirow[t]{2}{*}{$\mathrm{DTG}_{\max }\left({ }^{\circ} \mathrm{C}\right)$} & \multicolumn{2}{|c|}{$\%$ Estimated (calculated) } & \multirow{2}{*}{$\begin{array}{l}\text { Assignment } \\
\text { Lost species }\end{array}$} \\
\hline & & & Mass loss & Total mass loss & \\
\hline $\mathrm{L}_{1}$ & First step & $190,310,544,800$ & $92.36(92.07)$ & $92.36(92.07)$ & $8 \mathrm{C}_{2} \mathrm{H}_{2}+\mathrm{CO}+\mathrm{NH}_{3}+\mathrm{N}_{2}$ \\
\hline $305.19, \mathrm{C}_{19} \mathrm{H}_{19} \mathrm{ON}_{3}$ & Residue & & $7.64(7.86)$ & & $2 C$ \\
\hline$\left[\mathrm{Ag}\left(\mathrm{L}_{1}\right)_{2}\left(\mathrm{H}_{2} \mathrm{O}\right)_{2}\right] \mathrm{NO}_{3}$ & 1st step & 189 & $33.378(33.062)$ & $86.526(86.86)$ & $9 \mathrm{C}_{2} \mathrm{H}_{2}+2 \mathrm{H}_{2} \mathrm{O}$ \\
\hline \multirow[t]{2}{*}{ 816.65, $\mathrm{AgC}_{38} \mathrm{H}_{42} \mathrm{~N}_{7} \mathrm{O}_{7}$} & Second step & 366,562 & $52.79(53.798)$ & & $8 \mathrm{C}_{2} \mathrm{H}_{2}+4 \mathrm{HCN}+\mathrm{NO}+2 \mathrm{NO}_{2}$ \\
\hline & Residue & 807,931 & $13.474(13.14)$ & & $\mathrm{Ag}$ \\
\hline $\mathrm{L}_{2}$ & First step & $273,475,771$ & $86.70(86.56)$ & $86.7(86.56)$ & $6 \mathrm{C}_{2} \mathrm{H}_{2}++\mathrm{SO}+\mathrm{N}_{2}$ \\
\hline $268, \mathrm{C}_{15} \mathrm{H}_{12} \mathrm{~N}_{2} \mathrm{OS}$ & Residue & & $13.30(13.43)$ & & $3 C$ \\
\hline$\left[\mathrm{Ag}\left(\mathrm{L}_{2}\right)_{2}\left(\mathrm{H}_{2} \mathrm{O}\right)_{2}\right] \mathrm{NO}_{3} \cdot \mathrm{H}_{2} \mathrm{O}$ & First step & 99 & $2.08(2.37)$ & $75.90(76.404)$ & $\mathrm{H}_{2} \mathrm{O}$ \\
\hline \multirow[t]{2}{*}{ 760.59, $\mathrm{AgC}_{30} \mathrm{H}_{30} \mathrm{~N}_{5} \mathrm{O}_{8} \mathrm{~S}_{2}$} & Second step & 203,528 & $73.82(74.034)$ & & $\begin{array}{c}10 \mathrm{C}_{2} \mathrm{H}_{2}+4 \mathrm{HCN}+2 \mathrm{H}_{2} \mathrm{O}+\mathrm{N} \\
\mathrm{O}_{2}+\mathrm{SO}+\mathrm{SO}_{2}\end{array}$ \\
\hline & Residue & 881 & 23.35 (23.596) & & $\mathrm{Ag}+6 \mathrm{C}$ \\
\hline $\mathrm{L}_{3}$ & First step & 120,291 & $70.55(71.23)$ & $99.834(99.99)$ & $8 \mathrm{C}_{2} \mathrm{H}_{2}$ \\
\hline $292, \mathrm{C}_{18} \mathrm{H}_{16} \mathrm{O}_{2} \mathrm{~N}_{2}$ & Second step & 518 & $28.604(28.76)$ & & $2 \mathrm{CO}+\mathrm{N}_{2}$ \\
\hline$\left[\mathrm{Ag}\left(\mathrm{L}_{3}\right)_{2}\left(\mathrm{H}_{2} \mathrm{O}\right)_{2}\right] \mathrm{NO}_{3}$ & First step & 244 & $51.071(50.60)$ & $82.241(81.85)$ & $14 \mathrm{C}_{2} \mathrm{H}_{2}+2 \mathrm{H}_{2} \mathrm{O}$ \\
\hline \multirow[t]{2}{*}{ 790.57, $\mathrm{AgC}_{36} \mathrm{H}_{36} \mathrm{~N}_{5} \mathrm{O}_{9}$} & Second step & 534 & $31.17(31.25)$ & & $\mathrm{C}_{2} \mathrm{H}_{2}+\mathrm{CO}+2 \mathrm{HCN}+3 \mathrm{NO}_{2}$ \\
\hline & Residue & 677 & 17.76 (18.15) & & $A g+3 C$ \\
\hline
\end{tabular}

energy for complexes and reflect the thermal stability of the complexes [41].

\section{Mass spectra}

The principle of a mass spectrometer focuses on the separation of fragments of ions based on the distribution of these ions with the mass to charge ratio $(\mathrm{m} / \mathrm{z})$. The $\mathrm{L}_{1}, \mathrm{~L}_{2}, \mathrm{~L}_{3}$ fragmentation patterns and their complexes were obtained from the mass spectra, and were in good agreement with the structure suggested. The $\mathrm{L}_{1}$ showed molecular ion peak $\left(\mathrm{M}^{+}\right.$) with $\mathrm{m} / \mathrm{z}=305(100 \%)$. The molecular ion peak [a] losses $\mathrm{C}_{2} \mathrm{H}_{6} \mathrm{~N}$ to give fragment [b] at $\mathrm{m} / \mathrm{z}=261(3.13 \%)$, then [b] losses $\mathrm{C}_{6} \mathrm{H}_{4}$ to give fragment [c] at $\mathrm{m} / \mathrm{z}=185(2.98 \%)$ and [c] losses $\mathrm{CH}_{3} \mathrm{O}$ to give [d] at $\mathrm{m} / \mathrm{z}=154(0.66 \%)$. The molecular ion peak [a] losses $\mathrm{C}_{9} \mathrm{H}_{11} \mathrm{~N}$ to give fragment [e] at $\mathrm{m} / \mathrm{z}=172(29.92 \%)$ and this [e] losses $\mathrm{C}_{7} \mathrm{H}_{8} \mathrm{O}$ to give fragment [f] at $\mathrm{m} / \mathrm{z}=64$ (2.08\%) (Fig. 4), (Scheme 3). Fragmentation pattern of the complex $\left[\mathrm{Ag}\left(\mathrm{L}_{1}\right)_{2}\left(\mathrm{H}_{2} \mathrm{O}\right)_{2}\right] \mathrm{NO}_{3}$ is given as an example in (Fig. 4), Additional file 1: Scheme S1. The molecular ion peak [a] appeared at $\mathrm{m} / \mathrm{z}=816(20.5 \%)$ losses $\mathrm{C}_{18} \mathrm{H}_{22} \mathrm{~N}_{2}$ to give [b] at $\mathrm{m} / \mathrm{z}=514(17.7 \%)$ and it losses $\mathrm{C}_{2} \mathrm{H}_{6} \mathrm{O}_{2}$ to give $\left[\mathrm{c}\right.$ ] at $\mathrm{m} / \mathrm{z}=452(11.7 \%)$. The $\mathrm{L}_{2}$ molecular ion peak [a] appeared at $\mathrm{m} / \mathrm{z}=268(100 \%)$ losses $\mathrm{C}_{4} \mathrm{H}_{3} \mathrm{~S}$ to give [b] at $\mathrm{m} / \mathrm{z}=185(14.60 \%)$ then it losses $\mathrm{CH}_{3} \mathrm{O}$ to give [c] at $\mathrm{m} / \mathrm{z}=154(0.2 \%)$, molecular ion peak $[\mathrm{c}] \operatorname{loss}_{6} \mathrm{H}_{5}$ to give [d] at $\mathrm{m} / \mathrm{z}=77(28.34 \%)$ and molecular ion peak [d] losses $\mathrm{CH}$ to give $[\mathrm{e}]$ at $\mathrm{m} / \mathrm{z}=64$ (4.89\%).(Fig. 4), Scheme 4. Fragmentation pattern of the complex $\left[\mathrm{Ag}\left(\mathrm{L}_{2}\right)_{2}\left(\mathrm{H}_{2} \mathrm{O}\right)_{2}\right]$ $\mathrm{NO}_{3} \cdot \mathrm{H}_{2} \mathrm{O}$ is given as an example in (Fig. 4), Additional file 1: Scheme S2. The molecular ion peak [a] appeared at $\mathrm{m} / \mathrm{z}=760(35 \%)$ losses $\mathrm{C}_{10} \mathrm{H}_{8} \mathrm{~S}_{2}$ to give [b] at $\mathrm{m} / \mathrm{z}=532$ $(5 \%)$ and it losses $\mathrm{C}_{2} \mathrm{H}_{6} \mathrm{O}_{2}$ to give [c] at $\mathrm{m} / \mathrm{z}=470(12 \%)$. The $\mathrm{L}_{3}$ molecular ion peak [a] appeared at $\mathrm{m} / \mathrm{z}=292$ (100\%) losses $\mathrm{CH}_{3} \mathrm{O}$ to give [b] at $\mathrm{m} / \mathrm{z}=261(4 \%)$ then [a] losses $\mathrm{C}_{6} \mathrm{H}_{4}$ to give [c] at $\mathrm{m} / \mathrm{z}=185(21.73 \%)$, molecular ion peak[c] loss $\mathrm{CH}$ to give $[\mathrm{d}]$ at $\mathrm{m} / \mathrm{z}=172(6.8 \%)$ and molecular ion peak [d] losses $\mathrm{CH}_{3} \mathrm{O}$ to give [e] at $\mathrm{m} / \mathrm{z}=141$ (1.2\%).(Fig. 4), Scheme 5. Fragmentation pattern of the complex $\left[\mathrm{Ag}\left(\mathrm{L}_{3}\right)_{2}\left(\mathrm{H}_{2} \mathrm{O}\right)_{2}\right] \mathrm{NO}_{3}$ is given as an example in (Fig. 4), Additional file 1: Scheme S3. The molecular ion peak [a] appeared at $\mathrm{m} / \mathrm{z}=790(65 \%)$ losses $\mathrm{C}_{2} \mathrm{H}_{6} \mathrm{O}_{2}$ to give [b] at $\mathrm{m} / \mathrm{z}=692(2 \%)$, it losses $\mathrm{C}_{12} \mathrm{H}_{8}$ to give [c] at $\mathrm{m} / \mathrm{z}=540(12.5 \%)$ and molecular ion peak [c] losses $\mathrm{C}_{2} \mathrm{H}_{2}$ to give [d] at $\mathrm{m} / \mathrm{z}=514$ (25.3\%) [42].

\section{Biological activity studies Antimicrobial studies}

The antimicrobial efficacy of $\mathrm{L}_{1}, \mathrm{~L}_{2}, \mathrm{~L}_{3}$ and their free ligand complexes are explored in this experiment. Studies were conducted on E. Coli ATCC11229, Coliform ATCC8729, S. aureus ATCC6538, and Salmonella typhi ATCC14028 and fungal species as $A$. niger and $P$. expansum screening was tested against and examination and evaluation of the prepared complexes [42]. The same results were reported for $E$. Coli ATCC11229 of $\mathrm{Ag}(\mathrm{I})-\mathrm{L}_{2}$ and $\mathrm{Ag}(\mathrm{I})-\mathrm{L}_{1}$ followed by $\mathrm{Ag}(\mathrm{I})-\mathrm{L}_{3}$ considers that the lowest findings are equivalent to those of other complexes. The effect of free ligands on this strain has been shown to be below its complex and can be organized according to the sensitivity of the strains $L_{2}, L_{3}$ and $L_{1}$ in the following ascending order. The effect of Ligands and their 


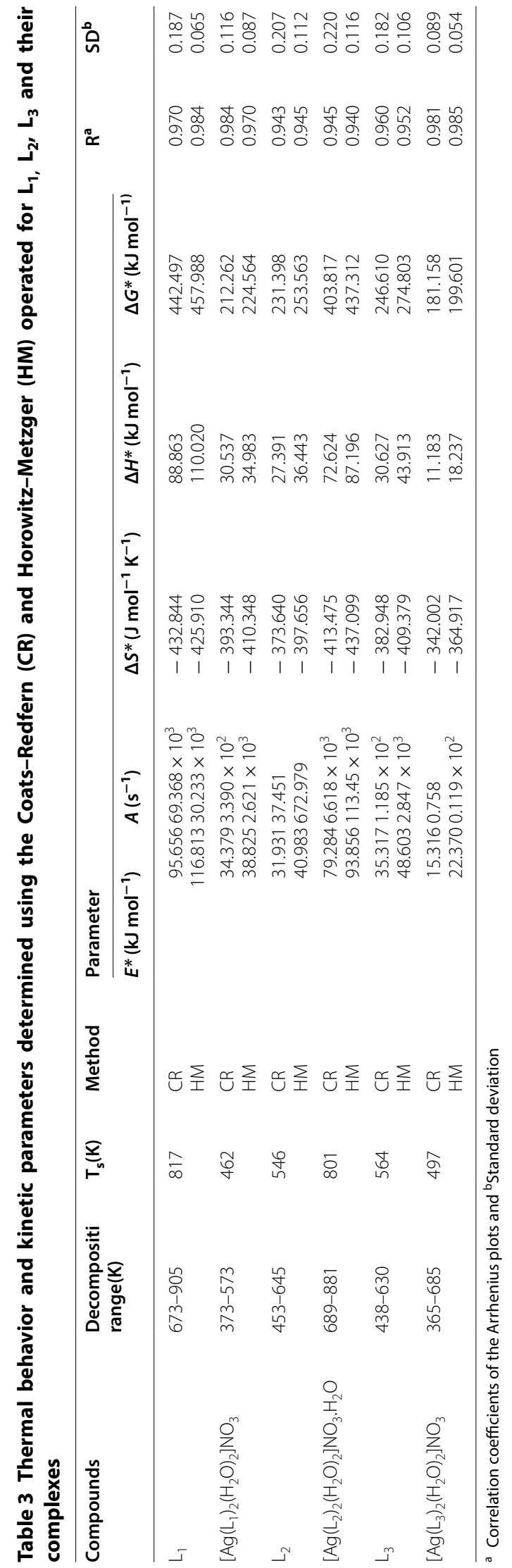



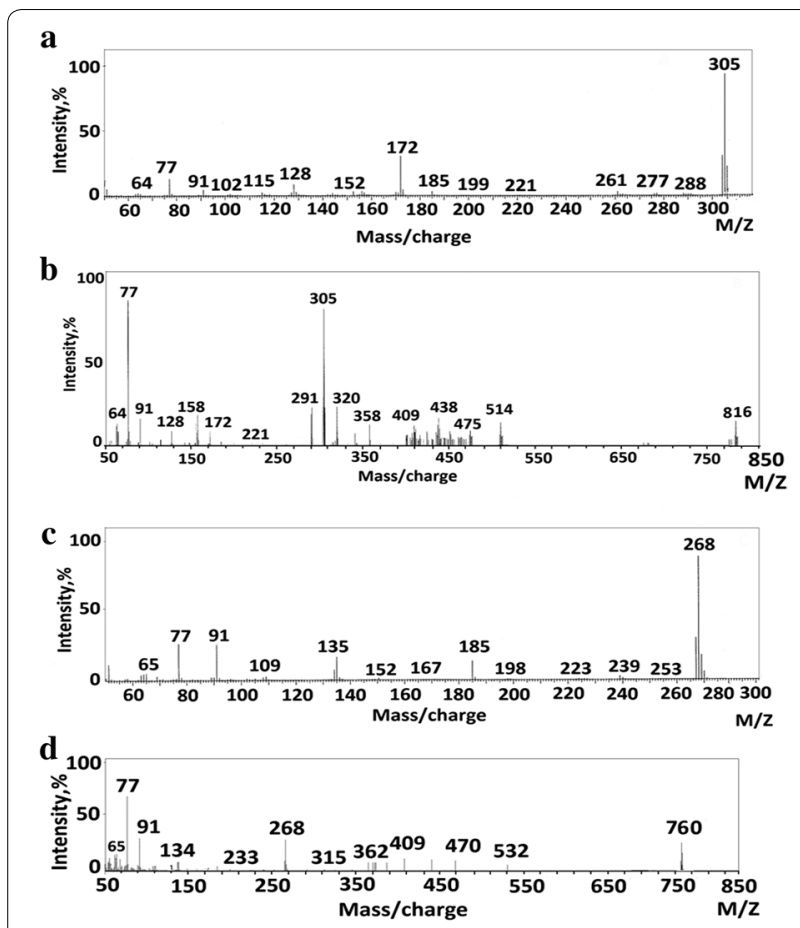

e
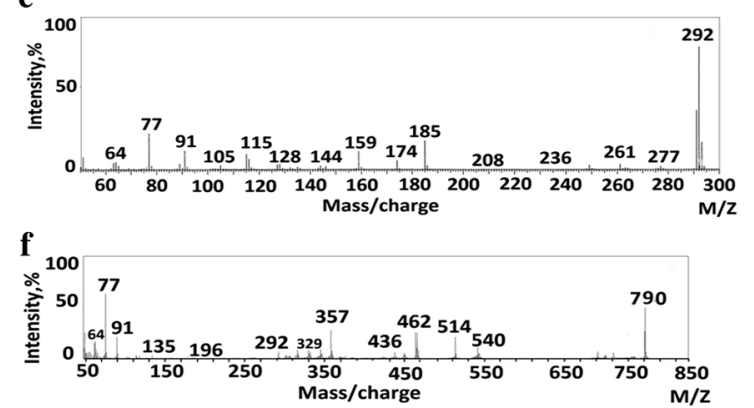

Fig. 4 Mass spectra diagrams for $(A) L_{1}$, (B) $\left[A g\left(L_{1}\right)_{2}\left(\mathrm{H}_{2} \mathrm{O}\right)_{2}\right] \mathrm{NO}_{3},(\mathrm{C}), \mathrm{L}_{2}$ (D) $\left[\mathrm{Ag}\left(\mathrm{L}_{2}\right)_{2}\left(\mathrm{H}_{2} \mathrm{O}\right)_{2}\right] \mathrm{NO}_{3} \cdot \mathrm{H}_{2} \mathrm{O}$, (E) $\mathrm{L}_{3}$ and $(\mathrm{F})\left[\mathrm{Ag}\left(\mathrm{L}_{3}\right)_{2}\left(\mathrm{H}_{2} \mathrm{O}\right)_{2}\right] \mathrm{NO}_{3}$

complexes on Coliform ATCC8729 showed that Ag(I)$\mathrm{L}_{2}$ is highly important, giving $25.12 \mathrm{~mm}$ respectively. Although the remaining complexes showed lower results than the $\mathrm{L}_{2}$ complexes. The results obtained in Table 4 and Fig. 5 showed that lower activity on the same strain and these results ensured that free ligand complexes were more active than free ligand complexes. In gram + ve bacteria, S. aureus ATCC6538, Highly important antibacterial activity of metal complexes with $\mathrm{L}_{1}$ followed $\mathrm{L}_{3}$ complex. The lesser activity from ligand $\mathrm{L}_{2}$ and its complex. The antibacterial activity of metal complexes on Salmonella typhi ATCC14028 showed a good activity against (gram - ve), that recorded the best results $\mathrm{Ag}(\mathrm{I})$ $\mathrm{L}_{3}>\operatorname{Ag}(\mathrm{I})-\mathrm{L}_{1}>\mathrm{Ag}(\mathrm{I})-\mathrm{L}_{2}$ respectively. The action of the free ligands on gram -ve bacteria has yielded results lower than their complexes which give respectively $12.6,11.43$ and $7.8 \mathrm{~mm}, \mathrm{~L}_{3}, \mathrm{~L}_{1}, \mathrm{~L}_{2}$. The presence of different ligands

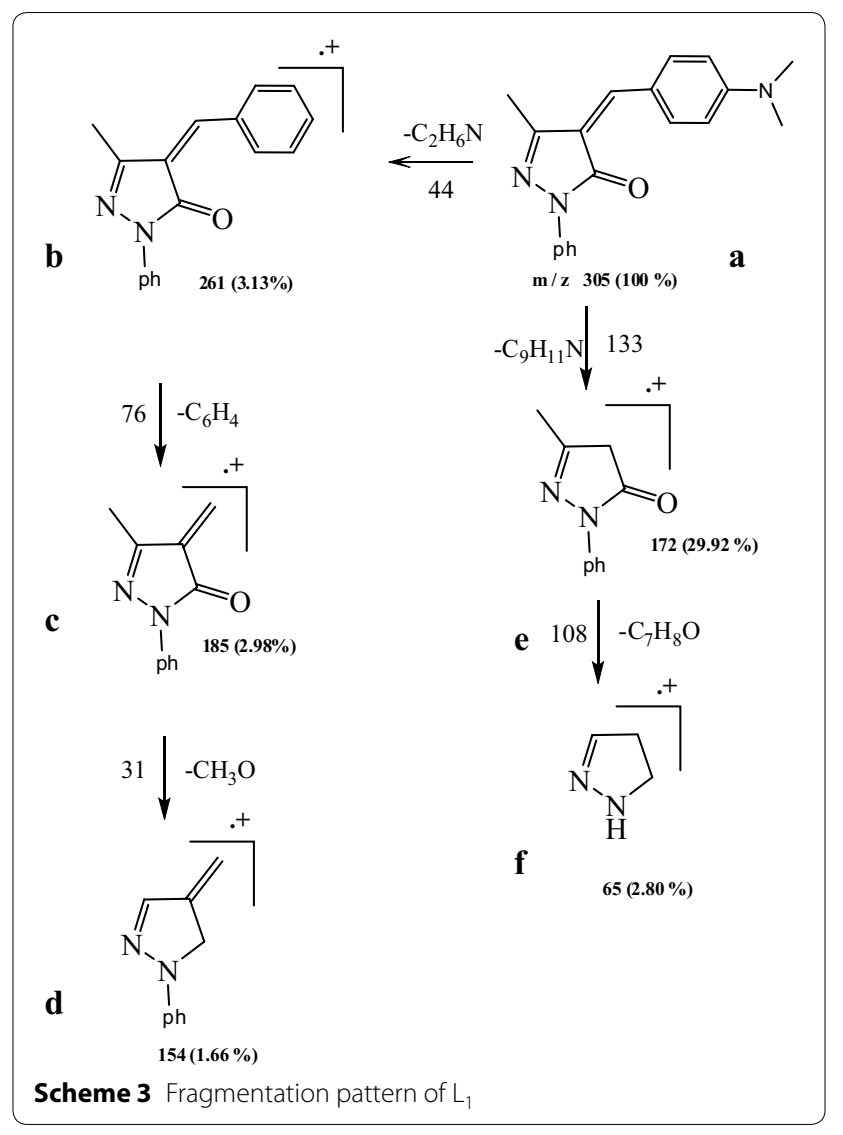

and other complexes on both fungal strains of the testes, $A$. niger recorded that $\mathrm{Ag}(\mathrm{I})-\mathrm{L}_{3}$ showed a significant difference the highly results $(20 \pm 2.6)$ though free $\mathrm{L}_{3}$ results showed less than its complex. Others did not show any activity against tested fungi $(A$. niger). The effect of various significant ligands and other complexes on $P$. expansum did not show any activity whereas the the highest broad spectrum of activity on the same test strain showed the best results on $\mathrm{L}_{1}$ and its complexes [42].

Normal antibiotic efficacy of antimicrobials (AMC, CTX, NS, FU). The AMC mixture give the effective against E. coli, Coliform, S. aureus and NS high inhibitory activity on $A$. niger. Other antibiotics have shown no action on other microorganisms. Eventually, the bacterial strains showed a varied response to the three free ligands and their complex antimicrobial activity, but the results indicated that the high activity of ligand complexes was better than their free ligands. The two fungal strains are more resistant to synthesis ligands and their complexes than bacterial strains [42-46].

\section{Determination of MIC for the most sensitive organisms}

The artificial ligands and their complexes developed the biological efficacy towaeds the more resistant 
a<smiles>CC1=NN(c2ccccc2)C(=O)/C1=C\c1cccs1</smiles>

m / z $268(100 \%)$

b<smiles>CCCCCCCCCCCCCCCCCCCCCCCCC</smiles><smiles>CO/C(C)=C1/C=NN(Pc2ccccc2)C1</smiles>

d<smiles>CC#CC1=CNNC1</smiles>

$77(28.34 \%)$<smiles>C1CNNC1</smiles>

$64(4.89 \%)$

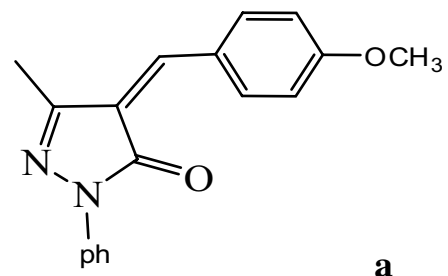

m / z $292(100 \%)$

a

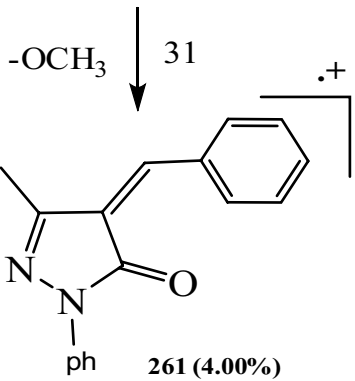

b

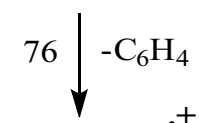

c

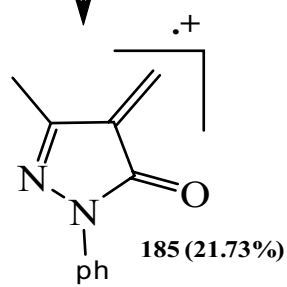

d
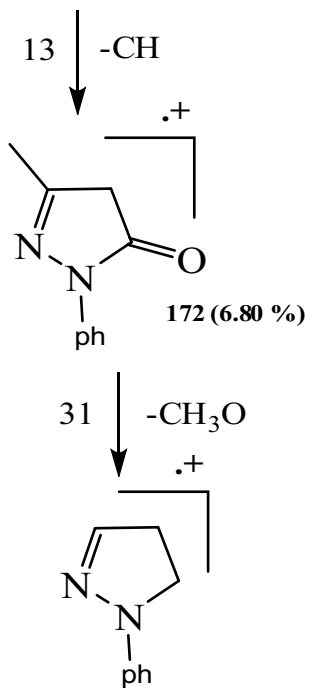

e

$141(1.20 \%)$

Scheme 5 Fragmentation pattern of $L_{3}$

bacteria and fungi (Table 5A-D) and Fig. 6). The order of The lowest MIC for in case of $E$. coli decrease in order: $\mathrm{L}_{1}=\mathrm{Ag}(\mathrm{I})-\mathrm{L}_{3}(0.02 \mathrm{mg} / 100 \mathrm{~mL})^{>} \mathrm{L}_{3}$ 
Table 4 The inhibitation diameters zone values $(\mathrm{mm})$ for $L_{1}, L_{2}, L_{3}$ and its complexes

\begin{tabular}{|c|c|c|c|c|c|c|c|}
\hline \multirow[t]{3}{*}{ Compounds } & & \multicolumn{6}{|c|}{ Microbial species } \\
\hline & & \multicolumn{4}{|l|}{ Bacteria } & \multicolumn{2}{|l|}{ Fungi } \\
\hline & & E. coli & Coliform & S. aureus & Salmonella typhi & A.niger & P.expansum \\
\hline $\mathrm{L}_{1}$ & & $10^{+1} \pm 1.1$ & $11^{+1} \pm 1.8$ & $12.5^{+1} \pm 0.89$ & $11.43^{+3} \pm 0.79$ & NA & $20^{+3} \pm 1.3$ \\
\hline $\mathrm{L}_{1} / \mathrm{Ag}(\mathrm{I})$ & & $29.33^{+2} \pm 1.58$ & $18.65^{+2} \pm 1.45$ & $22.6^{+1} \pm 1.88$ & $21.6^{+3} \pm 1.98$ & NA & $16^{+3} \pm 0.75$ \\
\hline $\mathrm{L}_{2}$ & & $14.66^{+1} \pm 1.1$ & $15.13^{+1} \pm 1.9$ & $6.25^{+1} \pm 0.81$ & $7.8^{+1} \pm 0.54$ & NA & NA \\
\hline $\mathrm{L}_{2} / \mathrm{Ag}(\mathrm{I})$ & & $29.6^{+2} \pm 1.75$ & $25.12^{+3} \pm 1.33$ & $9.5^{+1} \pm 0.74$ & $20^{+3} \pm 2.1$ & NA & NA \\
\hline $\mathrm{L}_{3}$ & & $11.2^{+1} \pm 1.4$ & $10.5^{+1} \pm 0.95$ & $13.6^{+1} \pm 1.3$ & $12.6^{+3} \pm 0.78$ & $14^{+2} \pm 0.75$ & NA \\
\hline $\mathrm{L}_{3} / \mathrm{Ag}(\mathrm{I})$ & & $22.16^{+1} \pm 2.4$ & $15.32^{+1} \pm 1.3$ & $20.8^{+1} \pm 2.2$ & $22^{+3} \pm 2.2$ & $20^{+3} \pm 2.6$ & NA \\
\hline $\mathrm{AgNO}_{3}$ & & & - & - & - & - & - \\
\hline Control (DMF) & & - & - & - & - & - & - \\
\hline \multirow[t]{4}{*}{ Standard } & Nystain & - & - & - & - & $11 \pm 1.1$ & 00 \\
\hline & Fluconazole & - & - & - & - & 00 & 00 \\
\hline & Amoxycillin/Clavulanic & $17 \pm 1.1$ & $14 \pm 1.3$ & $19 \pm 1.8$ & 00 & - & - \\
\hline & Cetaxime & 00 & 00 & 00 & 00 & - & - \\
\hline
\end{tabular}

Statistical significance $\mathrm{P}^{\mathrm{NS}}$ - $\mathrm{P}$ not significant, $P>0.05 ; \mathrm{P}^{+1}-\mathrm{P}$ significant, $P<0.05 ; \mathrm{P}^{+2}-\mathrm{P}$ highly significant, $P<0.01 ; \mathrm{P}^{+3}-\mathrm{P}$ very highly significant, $P>0.001 ;$ Student's $t$-test (Paired)

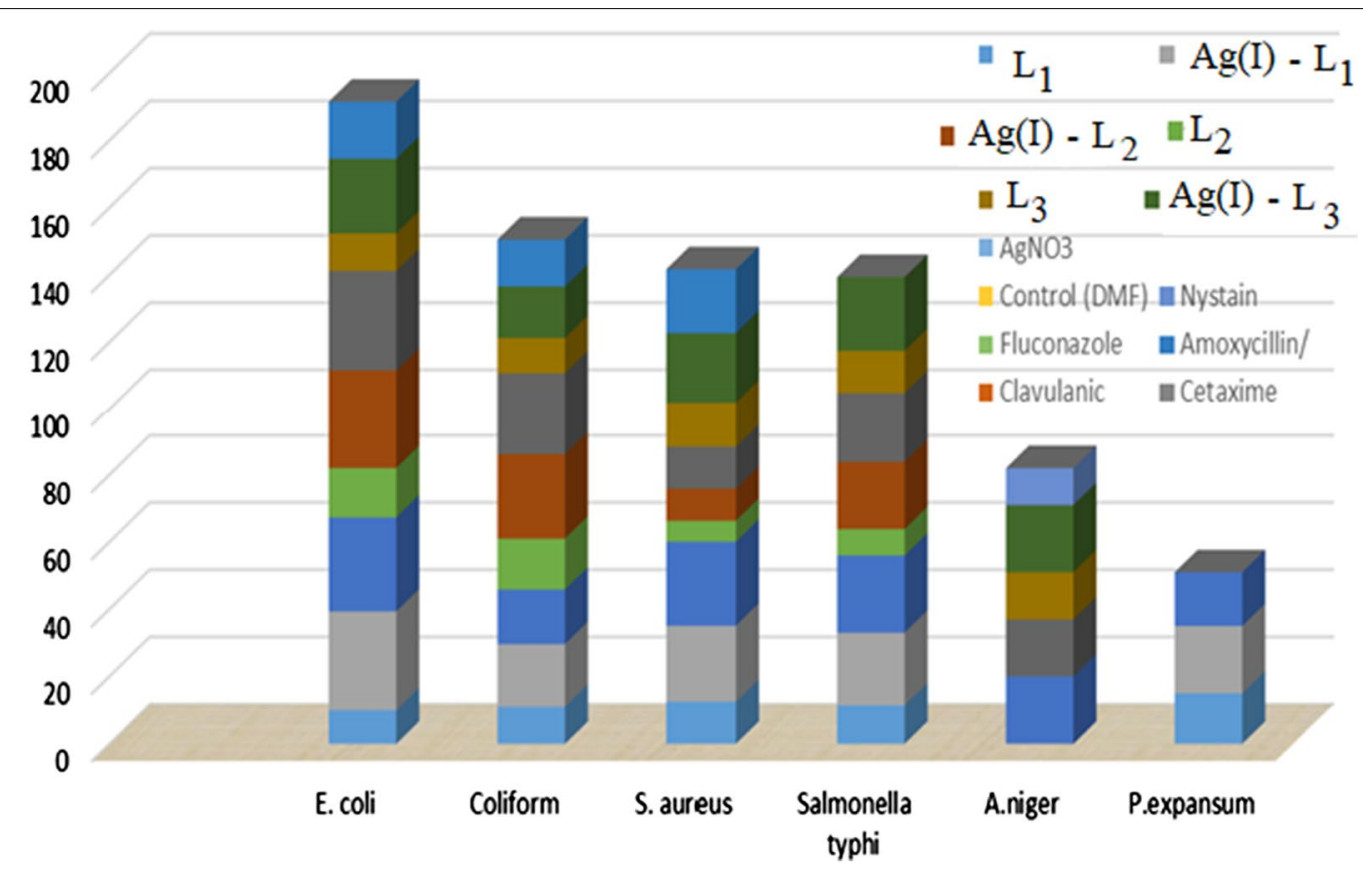

Fig. 5 Statistical representation for biological activity of $L_{1}, L_{2}, L_{3}$ and its metal complexes

$(0.05 \mathrm{mg} / 100 \mathrm{~mL})^{>} \mathrm{Ag}(\mathrm{I})-\mathrm{L}_{1}=\mathrm{L}_{2}(0.07 \mathrm{mg} / 100 \mathrm{~mL})$ $\mathrm{Ag}$ (I) $-\mathrm{L}_{2}(0.1 \mathrm{mg} / 100 \mathrm{~mL})$ [42], Coliform decrease in order: $\mathrm{Ag}(\mathrm{I})-\mathrm{L}_{2}(0.02 \mathrm{mg} / 100 \mathrm{~mL}){ }^{>} \mathrm{Ag}$ (I) $-\mathrm{L}_{3}=\mathrm{L}_{2}(0.07 \mathrm{mg} / 100 \mathrm{~mL}){ }^{>} \mathrm{L}_{1}=\mathrm{Ag}$ (I) $-\mathrm{L}_{1}=\mathrm{L}_{3}$ $(0.1 \mathrm{mg} / 100 \mathrm{~mL})$. Salmonella typhi showed that, the amazing results of ligands and its complexes: $\mathrm{L}_{2}, \mathrm{Ag}(\mathrm{I})$ $-\mathrm{L}_{2}=\mathrm{Ag}(\mathrm{I})-\mathrm{L}_{1}(0.02 \mathrm{mg} / 100 \mathrm{~mL})^{>} \mathrm{Ag}(\mathrm{I})-\mathrm{L}_{3}=\mathrm{L}_{1}($ $0.05 \mathrm{mg} / 100 \mathrm{~mL})^{>} \mathrm{L}_{3}(0.1 \mathrm{mg} / 100 \mathrm{~mL})$, S. aureus order:
$\mathrm{L}_{3}=\operatorname{Ag}(\mathrm{I})-\mathrm{L}_{2}=\operatorname{Ag}(\mathrm{I})-\mathrm{L}_{1}=\mathrm{L}_{1}=\operatorname{Ag}(\mathrm{I})-\mathrm{L}_{3}(0.1 \mathrm{mg} /$ $100 \mathrm{~mL})^{>} \mathrm{L}_{2}(0.05 \mathrm{mg} / 100 \mathrm{~mL})$. Table 5E, F and Fig. 6 data showed that the lowest MIC for the two strains measured at conc. $0.02 \mathrm{mg} / 100 \mathrm{~mL}$. Although MIC at complex $\mathrm{L}_{3}$ was recorded by A.niger, the same result was recorded on $\mathrm{Ag}(\mathrm{I})-\mathrm{L}_{3}$ at conc. $0.02 \mathrm{mg} / 100 \mathrm{~mL}$. Ligand $\mathrm{L}_{1}$ and its complexes demonstrate the strongest MIC on P. expansum, although no behavior is displayed 
Table 5 (A) Of One-way ANOVA: E. coli vs MIC Compounds. (B) Of One-way ANOVA: Coliform versus MIC Compounds. (C) Of One-way ANOVA: S. aureus vs MIC Compounds. (D) Of One-way ANOVA: Salm. typhi vs MIC Compounds. (E) Of Oneway ANOVA: A. niger vs MIC Compounds. (E) Of One-way ANOVA: A. niger vs MIC Compounds. (F) Of One-way ANOVA: P.expansum vs MIC Compounds

(A) Grouping information using the fisher LSD method

\begin{tabular}{llll}
\hline Compounds & N & Mean & Grouping \\
\hline$L_{1}$ & 3 & 0.02 & $\mathrm{~A}$ \\
$\mathrm{~L}_{3} / \mathrm{Ag}(I)$ & 3 & 0.02 & $\mathrm{~A}$ \\
$\mathrm{~L}_{3}$ & 3 & 0.05 & $\mathrm{~B}$ \\
$\mathrm{~L}_{1} / \mathrm{Ag}(I)$ & 3 & 0.07 & $\mathrm{~B}$ \\
$\mathrm{~L}_{2}$ & 3 & 0.07 & $\mathrm{~B}$ \\
$\mathrm{~L}_{2} / \mathrm{Ag}(I)$ & 3 & 0.10 & $\mathrm{C}$ \\
\hline
\end{tabular}

(B)

Grouping information using the fisher LSD method

\begin{tabular}{llll}
\hline Compounds & $\mathbf{N}$ & Mean & Grouping \\
\hline$L_{2} / A g(l)$ & 3 & 0.02 & $A$ \\
$L_{2}$ & 3 & 0.07 & $C$ \\
$L_{3} / A g(l)$ & 3 & 0.07 & $C$ \\
$L_{1}$ & 3 & 0.10 & $D$ \\
$L_{1} / A g(l)$ & 3 & 0.10 & $D$ \\
$L_{3}$ & 3 & 0.10 & $D$ \\
\hline
\end{tabular}

(C)

Grouping information using the fisher LSD method

\begin{tabular}{llll}
\hline Compounds & $\mathbf{N}$ & Mean & Grouping \\
\hline$L_{3} / \mathrm{Ag}(I)$ & 3 & 0.05 & $\mathrm{~A}$ \\
$\mathrm{~L}_{3}$ & 3 & 0.05 & $\mathrm{~A}$ \\
$\mathrm{~L}_{2} / \mathrm{Ag}(I)$ & 3 & 0.07 & $\mathrm{~B}$ \\
$\mathrm{~L}_{1} / \mathrm{Ag}(I)$ & 3 & 0.10 & $\mathrm{C}$ \\
$\mathrm{L}_{1}$ & 3 & 0.10 & $\mathrm{C}$ \\
$\mathrm{L}_{2}$ & 3 & 0.10 & $\mathrm{C}$ \\
\hline
\end{tabular}

(D)

Grouping information using the fisher LSD method

\begin{tabular}{llll}
\hline Compounds & N & Mean & Grouping \\
\hline$L_{1} / \mathrm{Ag}(I)$ & 3 & 0.02 & $\mathrm{~A}$ \\
$\mathrm{~L}_{2}$ & 3 & 0.02 & $\mathrm{~A}$ \\
$\mathrm{~L}_{2} / \mathrm{Ag}(I)$ & 3 & 0.02 & $\mathrm{~A}$ \\
$\mathrm{~L}_{1}$ & 3 & 0.05 & $\mathrm{~B}$ \\
$\mathrm{~L}_{3} / \mathrm{Ag}(I)$ & 3 & 0.05 & $\mathrm{~B}$ \\
$\mathrm{~L}_{3}$ & 3 & 0.10 & $\mathrm{C}$ \\
\hline
\end{tabular}

(E)

Grouping information using the fisher LSD method

\begin{tabular}{llll}
\hline Compounds & $\mathbf{N}$ & Mean & Grouping \\
\hline $\mathrm{L}_{3} / \mathrm{Ag}(I)$ & 3 & 0.02 & $\mathrm{~A}$ \\
$\mathrm{~L}_{3}$ & 3 & 0.02 & $\mathrm{~A}$ \\
$\mathrm{~L}_{2} / \mathrm{Ag}(I)$ & 3 & 0.0 & $\mathrm{~B}$ \\
\hline
\end{tabular}


Table 5 (continued)

(E)

\begin{tabular}{lclc}
\hline Grouping information using the fisher LSD method & & Mean \\
\hline Compounds & N & 0.0 & Grouping \\
\hline$L_{2}$ & 3 & 0.0 & $B$ \\
$L_{1} / A g(l)$ & 3 & 0.0 & $B$ \\
$L_{1}$ & 3 & $B$ \\
\hline
\end{tabular}

(F)

Grouping information using the fisher LSD method

\begin{tabular}{llll}
\hline Compounds & N & Mean & Grouping \\
\hline$L_{1} /$ Ag(l) & 3 & 0.02 & A \\
$L_{1}$ & 3 & 0.02 & $\mathrm{~A}$ \\
$L_{3} / \mathrm{Ag}(I)$ & 3 & 0.0 & $\mathrm{~B}$ \\
$\mathrm{~L}_{3}$ & 3 & 0.0 & $\mathrm{~B}$ \\
$\mathrm{~L}_{2} / \mathrm{Ag}(l)$ & 3 & 0.0 & $\mathrm{~B}$ \\
$\mathrm{~L}_{2}$ & 3 & 0.0 & $\mathrm{~B}$ \\
\hline
\end{tabular}

Means that do not share a letter are significantly different

Fisher 95\% Simultaneous Confidence Intervals

by the other compounds and their complexes. These findings ensured that the activity of synthetic ligands and their complexes on pathogenic bacteria and fungi demonstrated a minimum inhibitor concentration (MIC) for the most vulnerable pathogens. [42, 47, 48].

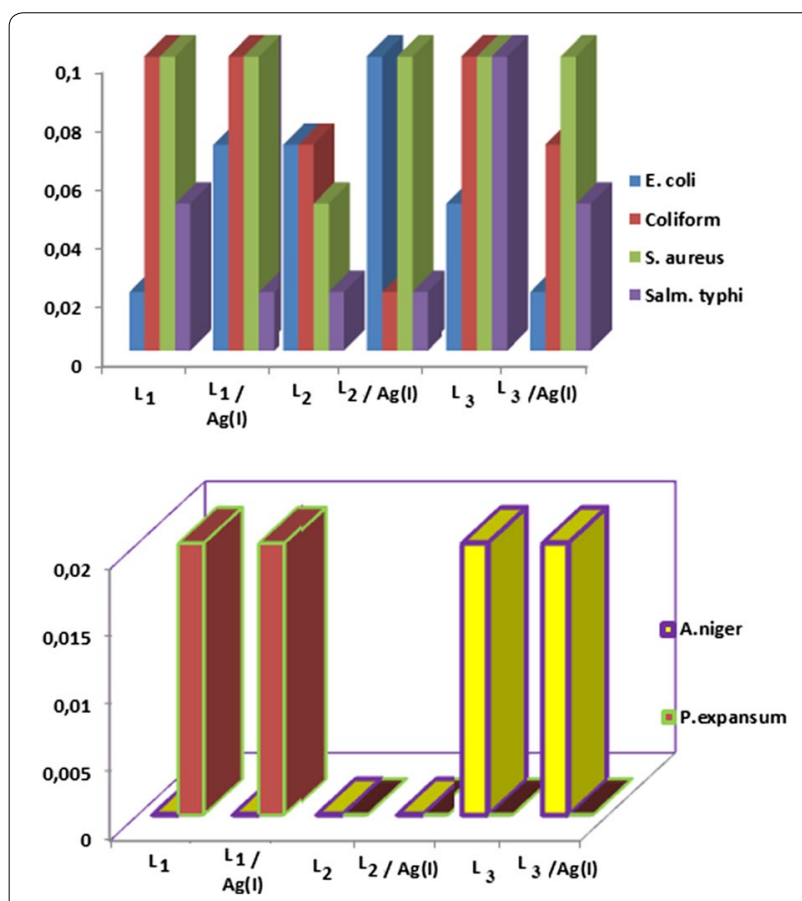

Fig. 6 MIC for the most sensitive organisms

\section{Conclusion}

Development and characterisation of three novel complexes of some replaced pyrazole derivatives as ligands (4-(4-dimethylamino benzylidene)-3-methyl-1-phenyl-1H-pyrazol-5(4H)-one (2a) $\mathrm{L}_{1}$, 4-(4-Thiophene)3-methyl-1-phenyl-1Hpyrazol-5 $(4 H)$-one (2b) $\mathrm{L}_{2}$, 4-(4-methoxy benzylidene)-3-methyl-1-phenyl$1 H$ pyrazol-5(4H)-one (2c) $\mathrm{L}_{3}$ ) with $\mathrm{Ag}(\mathrm{I})$ was achieved using physicochemical and spectroscopic methods.. In the resulting complexes, $\mathrm{L}_{1}, \mathrm{~L}_{2}$, and $\mathrm{L}_{3}$ were bound by the nitrogen atom to the metal ion via $v(C=N)$. For the three ligands and their complexes, thermogravimetric kinetic parameters and their differential were evaluated using the Coats-Redfern and Horowitz-Metzger equations. Metal complexes exhibited higher inhibition against all tested microorganisms and pathogenic bacteria and fungi and were the most susceptible pathogens with a minimum inhibitory concentration (MIC).

\section{Methods \\ Chemistry}

Analytical grade reagents, commercially available from multiple suppliers and used without further purification, were all the chemicals used in the complex preparation. Synthesized compounds and their complexes have been characterized by elemental analysis, magnetic and spectroscopic methods (IR, ${ }^{13} \mathrm{C},{ }^{1} \mathrm{HNMR}$, mass) and thermal analysis using the known apparatuses [42]. 


\section{Synthesis of the ligands}

Common 3-methyl-1-phenyl-5-pyrazolone synthesis technique (1)

Pure ethyl acetoacetate $(0.05 \mathrm{~mol}, 6.2 \mathrm{~mL})$ was mixed with pure phenyl hydrazine $(0.05 \mathrm{~mol}, 5 \mathrm{~mL}), 0.5 \mathrm{~mL}$ of acetic acid was added, according to knowm method [42]. Methyl phenyl pyrazolone was obtained as colorless crystals, $127^{\circ} \mathrm{C}$ melting point and 83.6 percent yield [27].

\section{Specific method for preparing derivatives of 4-arylidene-3-methyl-1-phenyl-5-pyrazolone (2a-c)}

The oil bath heated a mixture of 1-aryl-3-methyl-5-pyrazolone $(0.01 \mathrm{~mol}, 1.74 \mathrm{~g})$ and replaced aromatic aldehydes $(0.012 \mathrm{~mol})$ at $150-160{ }^{\circ} \mathrm{C}$ for 2 -4hrs. TLC has tracked the progress of the reaction using ethyl acetate: hexane (9:1) as solvent. The mixture was cooled, triturated and washed off with ether $(20 \mathrm{~mL})$. The colored residue was recrystallized from ethanol to provide the corresponding 4-arylidene-3-methyl-1-phenyl-5-pyrazolone (2a-c) as colored products, respectively [28].

4-(4-dimethylamino benzylidene)-3-methyl-1-phenyl-1 $H$-pyrazol-5(4H)-one $(2 \mathrm{a}) \mathrm{L}_{1}$.

4-(4-Thiophene)-3-methyl-1 - phenyl-1Hpyrazol$5(4 H)$-one $(2 \mathrm{~b}) \mathrm{L}_{2}$.

4-(4-methoxy benzylidene)-3-methyl-1-phenyl1Hpyrazol-5(4H)-one (2c) $\mathrm{L}_{3}$.

\section{4-(4-dimethylamino}

benzylidene)-3-methyl-1-phenyl-1 $H$-pyrazol-5(4H)-one

(2a) $L_{1}$

Brick Red, $\mathrm{mp}=170{ }^{\circ} \mathrm{C}$, yield $83 \% \mathrm{IR}\left(\mathrm{KBr}, v, \mathrm{~cm}^{-1}\right)$ : $3444(\mathrm{OH}), 1670(\mathrm{C}=\mathrm{O})$, and $1550 \mathrm{~cm}^{-1} \cdot{ }^{1} \mathrm{H}$ NMR $\left(\mathrm{DMSO}-d_{6}, 300 \mathrm{MHz}\right): \delta=2.28\left(\mathrm{~s}, 3 \mathrm{H}, \mathrm{CH}_{3}\right), 3.03$ $\left(\mathrm{s}, 6 \mathrm{H},-\mathrm{N}\left(\mathrm{CH}_{3}\right)_{2}\right), 7.14(\mathrm{~S}, 1 \mathrm{H},=\mathrm{CH}-\mathrm{Ar}), 9.66(\mathrm{~d}$, $3 \mathrm{H}, \mathrm{Ar}-\mathrm{H})$,. Anal. Calcd for $\mathrm{C}_{19} \mathrm{H}_{19} \mathrm{~N}_{3} \mathrm{O}$ (305.19): C, 74.40; H, 6.22; N 13.76; Found C, 74.23; H, 6.13; N, $13.35 \%$.

\section{4-(4-Thiophene)-3-methyl-1-phenyl-1Hpyrazol-5(4H)-one}

\section{(2b) $L_{2}$}

Orange, $\mathrm{mp}=125{ }^{\circ} \mathrm{C}$, yield $74 \%$ IR $\left(\mathrm{KBr}, v, \mathrm{~cm}^{-1}\right)$ : $3448(\mathrm{OH}), 1681(\mathrm{C}=\mathrm{O}), 1496 \mathrm{~cm}^{-1}(\mathrm{C}=\mathrm{N})$ and $1056 \mathrm{~cm}^{-1}(\mathrm{C}=\mathrm{S}) .{ }^{1} \mathrm{H}$ NMR (DMSO-d $\left.6,300 \mathrm{MHz}\right)$ : $\delta=2.30\left(\mathrm{~s}, 3 \mathrm{H}, \mathrm{CH}_{3}\right), 7.39(\mathrm{~S}, 1 \mathrm{H},=\mathrm{CH}-\mathrm{Ar}), 8.25(\mathrm{~d}$, $3 \mathrm{H}, \mathrm{Ar}-\mathrm{H}$ ). Anal. Calcd for $\mathrm{C}_{15} \mathrm{H}_{12} \mathrm{~N}_{2} \mathrm{OS}$ (268): C, 67.16; H, 4.47; N 10.44; S, 11.94; Found C, 67.00; H, 4.32; N, $10.21 ; \mathrm{S}, 11.65 \%$.

\section{4-(4-methoxy}

benzylidene)-3-methyl-1-phenyl-1Hpyrazol-5(4H)-one (2c) $\mathrm{L}_{3}$

Orange, $\mathrm{mp}=122{ }^{\circ} \mathrm{C}$, yield $82 \% \mathrm{IR}\left(\mathrm{KBr}, v, \mathrm{~cm}^{-1}\right): 3444$ $(\mathrm{OH}), 1678(\mathrm{C}=\mathrm{O}), 1508 \mathrm{~cm}^{-1}(\mathrm{C}=\mathrm{N})$ and. ${ }^{1} \mathrm{H}$ NMR
$\left(\mathrm{DMSO}-d_{6}, 300 \mathrm{MHz}\right): \delta=1.91\left(\mathrm{~s}, 3 \mathrm{H}, \mathrm{CH}_{3}\right), 3.69(\mathrm{~s}$, $3 \mathrm{H},-\mathrm{OCH}_{3}$ ), 7.20 (S, 1H, = CH-Ar), 8.71 (d, 3H, Ar-H). Anal. Calcd for $\mathrm{C}_{18} \mathrm{H}_{16} \mathrm{~N}_{2} \mathrm{O}_{2}$ (292): C, 73.97; H, 5.47; N 9.58; Found C, 73.78; H, 5.13; N, 9.34\%.

\section{Synthesis of the complexes}

The brown solid complex $\left[\mathrm{Ag}\left(\mathrm{L}_{1}\right)_{2}\left(\mathrm{H}_{2} \mathrm{O}\right)_{2}\right] \mathrm{NO}_{3}$ was prepared by adding $0.5 \mathrm{mmol}(0.085 \mathrm{~g})$ of $\mathrm{AgNO}_{3}$ in $20 \mathrm{ml}$ of acetone to a stirred suspended solution $1 \mathrm{mmol}(0.305 \mathrm{~g})$ of $\mathrm{L}_{1}$ in $50 \mathrm{ml}$ acetone. The reaction mixture was refluxed for $6 \mathrm{~h}$, the precipitate was drained off, washed several times with acetone and dried under vacuum over anhydrous $\mathrm{CaCl}_{2}$. Dark brown $\left[\mathrm{Ag}\left(\mathrm{L}_{2}\right)_{2}\left(\mathrm{H}_{2} \mathrm{O}\right)_{2}\right] \mathrm{NO}_{3} \cdot \mathrm{H}_{2} \mathrm{O}$, $\left[\mathrm{Ag}\left(\mathrm{L}_{3}\right)_{2}\left(\mathrm{H}_{2} \mathrm{O}\right)_{2}\right] \mathrm{NO}_{3}$ solid complexes were prepared in the same manner as mentioned above.

\section{$\left[\mathrm{Ag}\left(\mathrm{C}_{19} \mathrm{H}_{19} \mathrm{~N}_{3} \mathrm{O}\right)_{2}\left(\mathrm{H}_{2} \mathrm{O}\right)_{2}\right] \mathrm{NO}_{3}\left(\mathrm{AgC}_{38} \mathrm{H}_{42} \mathrm{~N}_{7} \mathrm{O}_{7}\right)$ complex} Brown; Yield: 85\%; m.p.: $160{ }^{\circ} \mathrm{C}$; M.Wt: 816.65; Elemental analysis for $\mathrm{AgC}_{38} \mathrm{H}_{42} \mathrm{~N}_{7} \mathrm{O}_{7}$ : found, C, 55.31; H, 4.99; N, 12.00; Ag, 13.14; Calcd, C 55.89; H, 5.18; N, 12.01; Ag, $13.21 ; \Lambda_{\mathrm{m}}=115.75 \mathrm{~S} \mathrm{~cm}^{2} \mathrm{~mol}^{-1}$; IR $\left(\mathrm{KBr}, v, \mathrm{~cm}^{-1}\right)$ : $3450 \mathrm{~m}$,br $(\mathrm{OH}), 1666 \mathrm{~m}(\mathrm{C}=\mathrm{O}), 1523 \mathrm{vw} \mathrm{cm} \mathrm{cm}^{-1}(\mathrm{C}=\mathrm{N})$ and $813 \mathrm{w}$ and $837 \mathrm{w}(\mathrm{M}-\mathrm{N}) .{ }^{1} \mathrm{H}$ NMR (DMSO- $d_{6}$, $300 \mathrm{MHz}): \delta=2.49\left(\mathrm{~s}, 3 \mathrm{H}, \mathrm{CH}_{3}\right), 3.46\left(\mathrm{~s}, 2 \mathrm{H}, \mathrm{H}_{2} \mathrm{O}\right), 2.27-$ $2.33\left(\mathrm{~s}, 6 \mathrm{H},-\mathrm{N}\left(\mathrm{CH}_{3}\right)_{2}\right), 9.67(\mathrm{~S}, 1 \mathrm{H},=\mathrm{CH}-\mathrm{Ar}), 7.14-7.97$ (m, 4H, Ar-H).

\section{$\left[\mathrm{Ag}\left(\mathrm{C}_{15} \mathrm{H}_{12} \mathrm{~N}_{2} \mathrm{OS}\right)_{2}\left(\mathrm{H}_{2} \mathrm{O}\right)_{2}\right] \mathrm{NO}_{3} \cdot \mathrm{H}_{2} \mathrm{O}\left(\mathrm{AgC}_{30} \mathrm{H}_{30} \mathrm{~N}_{5} \mathrm{O}_{8} \mathrm{~S}_{2}\right)$ complex}

Dark brown; Yield: 74\%; m.p.: $125^{\circ} \mathrm{C}$; M.Wt: 760.59; Elemental analysis for $\mathrm{AgC}_{30} \mathrm{H}_{30} \mathrm{~N}_{5} \mathrm{O}_{8} \mathrm{~S}_{2}$ : found, $\mathrm{C}, 47.22 ; \mathrm{H}$, 3.91; N, 9.15; Ag, 14.13; Calcd, C, 47.37; H, 3.98; N, 9.21; Ag, 14.18; $\Lambda_{\mathrm{m}}=135.50 \mathrm{~S} \mathrm{~cm}^{2} \mathrm{~mol}^{-1}$; IR $\left(\mathrm{KBr}, v, \mathrm{~cm}^{-1}\right)$ : $3444 \mathrm{~m}$, br $(\mathrm{OH}), 1685 \mathrm{~m}(\mathrm{C}=\mathrm{O}), 1527 \mathrm{vw} \mathrm{cm}{ }^{-1}(\mathrm{C}=\mathrm{N})$, $1099 \mathrm{~m} \mathrm{~cm}^{-1}(\mathrm{C}=\mathrm{S}), 748 \mathrm{w}$ and $792 \mathrm{w}(\mathrm{M}-\mathrm{N}) .{ }^{1} \mathrm{H}$ NMR $\left(\mathrm{DMSO}-d_{6}, 300 \mathrm{MHz}\right): \delta=2.49\left(\mathrm{~s}, 3 \mathrm{H}, \mathrm{CH}_{3}\right), 3.37(\mathrm{~s}, 2 \mathrm{H}$, $\left.\mathrm{H}_{2} \mathrm{O}\right)$, 8.64 (S, 1H, = CH-Ar), 7.20-7.94 (d, 3H, Ar-H).

\section{$\left[\mathrm{Ag}\left(\mathrm{C}_{18} \mathrm{H}_{16} \mathrm{~N}_{2} \mathrm{O}_{2}\right)_{2}\left(\mathrm{H}_{2} \mathrm{O}\right)_{2}\right] \mathrm{NO}_{3}\left(\mathrm{AgC}_{36} \mathrm{H}_{36} \mathrm{~N}_{5} \mathrm{O}_{9}\right)$ complex} Dark brown; Yield: 90\%; m.p.: $150{ }^{\circ} \mathrm{C}$; M.Wt: 790.57; Elemental analysis for $\mathrm{AgC}_{36} \mathrm{H}_{36} \mathrm{~N}_{5} \mathrm{O}_{9}$ : found, $\mathrm{C}, 54.47 ; \mathrm{H}$, 4.11; N, 8.80; Ag, 13.60; Calcd, C, 54.69; H, 4.59; N, 8.86; Ag, 13.64; $\Lambda_{\mathrm{m}}=114.52 \mathrm{~S} \mathrm{~cm}^{2} \mathrm{~mol}^{-1}$; IR $\left(\mathrm{KBr}, v, \mathrm{~cm}^{-1}\right)$ : 3444 $(\mathrm{OH}), 1678(\mathrm{C}=\mathrm{O}), 1520 \mathrm{~cm}^{-1}(\mathrm{C}=\mathrm{N}), 759 \mathrm{w}$ and $779 \mathrm{w}(\mathrm{M}-\mathrm{N}) .{ }^{1} \mathrm{H}$ NMR (DMSO- $\left.d_{6}, 300 \mathrm{MHz}\right): \delta=2.33$ $\left(\mathrm{s}, 3 \mathrm{H}, \mathrm{CH}_{3}\right), 3.31\left(\mathrm{~s}, 3 \mathrm{H},-\mathrm{OCH}_{3}\right), 8.42(\mathrm{~S}, 1 \mathrm{H},=\mathrm{CH}-\mathrm{Ar})$, 7.18-7.46 (d, 3H, Ar-H).

\section{Supplementary information}

Supplementary information accompanies this paper at https://doi. org/10.1186/s13065-020-00723-0. 
Additional file 1: Table S1. UV-Vis. spectral data of the free ligand $L_{1}$, $L_{2}, L_{3}$ and their $A g(I)$-complexes. Table S2. Selected ${ }^{1} H$ NMR data of $L_{1}$, $L_{2}, L_{3}$ and its diamagnetic complexes. Fig. S1. TGA and DTG diagrams for $\mathbf{a} \mathrm{L}_{1}, \mathbf{b}\left[\mathrm{Ag}\left(\mathrm{L}_{1}\right)_{2}\left(\mathrm{H}_{2} \mathrm{O}\right)_{2}\right] \mathrm{NO}_{3}, \mathbf{c}, \mathrm{L}_{2} \mathbf{d}\left[\mathrm{Ag}\left(\mathrm{L}_{2}\right)_{2}\left(\mathrm{H}_{2} \mathrm{O}\right)_{2}\right] \mathrm{NO}_{3} . \mathrm{H}_{2} \mathrm{O}, \mathbf{e ~} \mathrm{L}_{3}$ and f $\left[\mathrm{Ag}\left(\mathrm{L}_{3}\right)_{2}\left(\mathrm{H}_{2} \mathrm{O}\right)_{2}\right] \mathrm{NO}_{3}$. Fig. S2. The diagrams of kinetic parameters of $\mathrm{L}_{1}$, $\left[\mathrm{Ag}\left(\mathrm{L}_{1}\right)_{2}\left(\mathrm{H}_{2} \mathrm{O}\right)_{2}\right] \mathrm{NO}_{3}, \mathrm{~L}_{2},\left[\mathrm{Ag}\left(\mathrm{L}_{2}\right)_{2}\left(\mathrm{H}_{2} \mathrm{O}\right)_{2}\right] \mathrm{NO}_{3} \cdot \mathrm{H}_{2} \mathrm{O}, \mathrm{L}_{3}$ and $\left[\mathrm{Ag}\left(\mathrm{L}_{3}\right)_{2}\left(\mathrm{H}_{2} \mathrm{O}\right)_{2}\right]$ $\mathrm{NO}_{3}$ using Coats-Redfern (CR) and Horowitz-Metzger (HM) equations. Scheme S1. Fragmentation pattern of $\left[\mathrm{Ag}\left(\mathrm{L}_{1}\right)_{2}\left(\mathrm{H}_{2} \mathrm{O}\right)_{2}\right] \mathrm{NO}_{3}$. Scheme S2. Fragmentation pattern of $\left[\mathrm{Ag}\left(\mathrm{L}_{2}\right)_{2}\left(\mathrm{H}_{2} \mathrm{O}\right)_{2}\right] \mathrm{NO}_{3} \cdot \mathrm{H}_{2} \mathrm{O}$. Scheme S3. Fragmentation pattern of $\left[\mathrm{Ag}\left(\mathrm{L}_{3}\right)_{2}\left(\mathrm{H}_{2} \mathrm{O}\right)_{2}\right] \mathrm{NO}_{3}$

\section{Abbreviations}

EtOH: Ethanol; NMR: Nuclear magnetic resonance; IR: Infrared radiation; DMSO: Dimethyl sulfoxide; MIC: Minimum inhibation concentrations.

\section{Acknowledgements}

The authors gratefully acknowledge to Zagazig University (http://www.Zu.edu. eg/), Egypt, Univeristy of Bisha, Saudi Arabia and Center for Advanced Materials, Qatar University, Doha, for the support of this research work.

\section{Authors' contributions}

WSS and WHE carried the literature and designed synthetic schemes (synthesis and Purifcation) and records the ${ }^{13}$ CNMR of all compounds. SFM, AMA, MHS and WHE designed the research study and wrote the manuscript. WHE carried out the spectroscopic analysis and carried out the antimicrobial assays. WSS and WHE discussed the results and revised the manuscript. All authors read and approved the fnal manuscript.

\section{Funding}

This research is not funded though any source to This publication was supported by Qatar University, internal grant number QUCG-CAM-20/21-2. The findings achieved herein are solely the responsibility of the authors.

\section{Availability of data and materials}

The datasets used and/or analysed during the current study available from the corresponding author on reasonable request.

\section{Ethics approval and consent to participate}

Not applicable.

\section{Consent for publication}

All authors consent to publication.

\section{Competing interests}

The authors declare that they have no competing interests.

\section{Author details}

${ }^{1}$ Department of Chemistry, Faculty of Science, Zagazig University, Zagazig 44519, Egypt. ${ }^{2}$ Center for Advanced Materials, Qatar University, P.O. Box 2713, Doha, Qatar. ${ }^{3}$ Department of Chemistry, College of Science, University of Bisha, Bisha 61922, Saudi Arabia.

Received: 14 August 2020 Accepted: 27 November 2020

Published online: 05 December 2020

\section{References:}

1. Daniele C, Alessandro DL, Marco R et al (2008) Synthesis, biological evaluation and SAR study of novel pyrazole analogues as inhibitors of Mycobacterium tuberculosis. Bioorg Med Chem 16(18):8587-8591

2. Castagnolo DMF, Radi M, Bechi B et al (2009) Synthesis, biological evaluation, and SAR study of novel pyrazole analogues as inhibitors of Mycobacterium tuberculosis: part 2. Synthesis of rigid pyrazolones. Bioorg Med Chem 17(15):5716-5721
3. Anshu D, Ruby S, Dharmendra S et al (2010) Regioselective Synthesis of Diltiazem Analogue Pyrazolo[4,3-c][1,5]benzothiazepines and Antifungal Activity. Phosphorus Sulfur Silicon Relat Elem 185(12):2472-2479

4. Sureshkumar EV, Rao RM et al (2012) Synthesis, characterization and biological evaluation of novel pyrazole ring contain mannich derivatives. Der Pharma Chemica 4(2):707-713

5. Ouyang G, Chen Z, Cai XJ, Song BA et al (2008) Synthesis and antiviral activity of novel pyrazole derivatives containing oxime esters group. Bioorg Med Chem 16(22):9699-9707

6. Idrees GA, Aly OM, Abuo-Rahma GEAA et al (2009) Design, synthesis and hypolipidemic activity of novel 2-(naphthalen-2-yloxy)propionic acid derivatives as desmethyl fibrate analogs. Eur J Med Chem 44(10):3973-3980

7. Hu Y, Wei P, Zhou H et al (2006) Organic synthesis in ionic liquids: condensation of 3-Methyl-1-phenyl-5-pyrazolone with carbonyl compounds catalyzed by ethylenediammonium diacetate (EDDA). Chin Chem Lett 17:299-301

8. Umesha KB, Rai KML, Nayaka MAH (2009) Antioxidant and Antimicrobial Activity of 5-methyl-2-(5-methyl-1, 3-diphenyl-1H-pyrazole-4-carbonyl)-2, 4-dihydro-pyrazol-3-one. Inter J Biomed Sci 5(4):359

9. Dongmei L, Liping S, Shaodi S et al (2007) Regioselective synthesis of 6-trifluoromethyl-1,4,5,6-tetrahydropyrazolo[3,4-b]pyran derivatives. J Fluorine Chem 128(8):952-957

10. Xiao-Liu L, Yong-Mei W, Bing T et al (1998) The solid-state michael addition of 3-methyl-1-phenyl-5-pyrazolone. J Heterocycl Chem 35(1):129-134

11. Mohd A, Shikha K (2005) Synthesis and anti-inflammatory, analgesic, ulcerogenic and lipid peroxidation activities of 3,5-dimethyl pyrazoles, 3-methylpyrazol-5-ones and 3,5-disubstituted pyrazolines, Indian. J Chem 44B:2532-2537

12. Vijesh AM, Arun MI, Shrikrishna I et al (2011) Synthesis of some new pyrazolone derivatives as potent antimicrobial agents. Der Pharma Chemica 3(4):454-463

13. Mohamed A, Gamal EAA, Alaa AH (2009) Synthesis of novel pyrazole derivatives and evaluation of their antidepressant and anticonvulsant activities. Eur J Med Chem 44(9):3480-3487

14. Mahindra TM, Rajesh TK, Vithal MK et al (2004) De novo design and synthesis of HIV-1 integrase inhibitors. Bioorg Med Chem 12(9):2317-2333

15. Das N, Verma A, Shrivastava PK (2008) Synthesis and biological evaluation of some new aryl pyrazol-3-one derivatives as potential hypoglycemic agents. Indian J Chem 47B(10):1555-1558

16. Manojkumar P, Ravi TK (2009) Subbuchettiar, G. Synthesis of coumarin heterocyclic derivatives with antioxidant activity and in vitro cytotoxic activity against tumour cells. Acta Pharm 59:159-170

17. Rishikesh VA, Cendilkumar A, Gurubasavrajswamy PM et al (2011) Pyrazolone part 3: Antibacterial activity of novel 4-substituted pyrazolone derivatives. Der Pharma Chemica 3(5):7-12

18. Bondock S, Rabie R, Etman HA, Fadda AA (2008) Synthesis and antimicrobial activity of some new heterocycles incorporating antipyrine moiety. Eur J Med Chem 43(10):2122-2129

19. Rostom SAF, El-Ashmawy IM, Abd El Razik HA et al (2009) Design and synthesis of some thiazolyl and thiadiazolyl derivatives of antipyrine as potential non-acidic anti-inflammatory, analgesic and antimicrobial agents. Bioorg Med Chem 17:882-895

20. Kucukguzel SG, Rollas S, Erdeniz H et al (2000) Synthesis, characterization and pharmacological properties of some 4-arylhydrazono-2-pyrazoline-5one derivatives obtained from heterocyclic amines. Eur J Med Chem 35(7-8):761-771

21. Meng L, Bao-Xiang Z (2014) Progress of the synthesis of condensed pyrazole derivatives (from 2010 to mid-2013). Eur J Med Chem 85:311-340

22. Douglass FT, Pavan KT (2011) Indole synthesis: a review and proposed classification. Tetrahedron 67:7195-7210

23. Demetrio R, Benedetta M, Maria VR (2015) Recent advanced in bioactive systems containing pyrazole fused with a five membered heterocycle. Eur J Med Chem 97:732-756

24. Frederick EB, Vara Prasad JVN, Allison LC et al (2007) Synthesis and SAR of novel conformationally-restricted oxazolidinones possessing Gram-positive and fastidious Gram-negative antibacterial activity. Part 1: substituted pyrazoles. J Bioorg Med Chem Lett. 17(16):4694-4698 
25. Paul S, Jim CC, Alan H, Paul GG (2019) The variable toxicity of silver ions in cell culture media. Toxicol In Vitro 60:154-159

26. Tomislav B, Franc P, Tomislav M et al (2020) Ligand influence on the formation of exo-coordinated silver(I) complexes with $\mathrm{N}_{2} \mathrm{O}_{2}$ Schiff base macrocycles and the role of anion in supramolecular aggregation. Polyhedron 190:114774

27. Mann FG, Saunders BC (1960) In practical organic chemistry, 4th edn. New Impression, Orient Longman Ltd., New Delhi, p 271

28. Salem AB (2008) Thermal condensation of 1-Aryl/ hetaryl-3-methyl2-pyrazolin-5-ones with Aromatic Aldehydes. Synthesis of 4-arylidenepyrazolones. JKAU 20(2):93-100

29. Singh V, Katiyar A, Singh S (2008) Synthesis, characterization of some transition metal (II) complexes of acetone p-amino acetophenone salicyloyl hydrazone and their anti microbial activity. Biometals 21(4):491-501

30. El-Shwiniy WH, Shehab WS, Zordok WA (2020) Spectral, thermal, DFT calculations, anticancer and antimicrobial studies for bivalent manganese complexes of pyrano[2,3-d]pyrimidine derivatives. J Mol Struct 1199:126993

31. Shehab WS, El-Shwiniy WH (2018) Nanoparticles of manganese oxides as efcient catalyst for the synthesis of pyrano[2,3-d]pyrimidine derivatives and their complexes as potent protease inhibitors. J Iran Chem Soc 15:431

32. El-Megharbel SM, Hamza RZ, Refat MS (2014) Synthesis, chemical identification, antioxidant capacities and immunological evaluation studies of a novel silver(I) carbocysteine complex. Chem-Biol Interact 220:169

33. Abo-Aly MM, Salem AM, Sayed MA et al (2015) Spectroscopic and structural studies of the Schiff base 3-methoxy-N-salicylidene-o-amino phenol complexes with some Transition metal ions and their antibacterial, antifungal. Spectrochim Acta A 136:993-1000

34. Khalil SME, Seleem HS, Shetary BA et al (2002) Mono- and Bi-nuclear metal complexes of schiff-base hydrazone (ONN) derived from o-hydroxyacetophenone and 2-amino-4-hydrazino-6-methyl pyrimidine. J Coord Chem 55(8):883-899

35. Bin H, Gang W, Wei Y et al (2011) Azo-hydrazone tautomerism by in situ Cull ion catalysis and complexation with the $\mathrm{H} 2 \mathrm{O} 2$ oxidant of C.I. Disperse Yellow 79. Dyes Pigm. 91(2):105

36. Sultana N, Arayne MS, Gul S et al (2010) Sparfloxacin-metal complexes as antifungal agents - their synthesis, characterization and antimicrobial activities. J Mol Struct 975:285
37. Sadeek SA, Refat MS, Hashem HA (2006) Complexation and thermogravimetric investigation on tin(II) and tin(IV) with norfloxacin as antibacterial agent. J Coord Chem 59:759-775

38. Skauge T, Turel I, Sletten E (2002) Interaction between ciprofloxacin and DNA mediated by $\mathrm{Mg}^{2+}$-ions. Inorg Chem Acta 339:239-247

39. Coats AW, Redfern JP (1964) Kinetic parameters from thermogravimetric data. Nature 201:68-69

40. Horowitz HW, Metzger G (1963) A new analysis of thermogravimetric traces. Anal Chem 35:1464

41. Sestak J, Satava V, Wendlandt WW (1973) The study of heterogeneous processes by thermal analysis. Thermochim Acta 7(5):333-334

42. El-Shwiniy WH, Shehab WS, Mohamed SF, Ibrahium HG (2018) Synthesis and cytotoxic evaluation of some substituted pyrazole zirconium (IV) complexes and their biological assay. Appl Organometal Chem 32:e4503

43. Elshwiniy WH, Asmaa Gl, Sadeek AS et al (2020) Ligational, density functional theory, and biological studies on some new Schiff base 2-(2-hydroxyphenylimine)benzoic acid (L) metal complexes. Appl Organomet Chem 34:e5819

44. Okulik N, Jubert AH (2005) Theoretical analysis of the reactive sites of non-steroidal anti-inflammatory drugs. Internet Electron J Mol Des 4:17

45. Zaky RR, Yousef TA (2011) Spectral, magnetic, thermal, molecular modelling, ESR studies and antimicrobial activity of (E)-3-(2-(2-hydroxybenzylidene) hydrazinyl)-3-oxo-n (thiazole-2-yl) propanamide. J Mol Str 1002:76

46. Mohamed GG, Sharaby CM (2007) Metal complexes of Schiff base derived from sulphametrole and o-vanilin Synthesis, spectral, thermal characterization and biological activity. Spectrochim Acta A 66:949

47. Efthimiadou EK, Katsaros N, Karaliota A et al (2007) Synthesis, characterization, antibacterial activity, and interaction with DNA of the vanadylenrofloxacin complex. Bioorg Med Chem Lett 17:1238-1242

48. Dharmaraj N Viswanathamurthi P, Natarajan K (2001) Ruthenium(II) complexes containing bidentate Schiff bases and their antifungal activity. Transit Met Chem 26:105-109

\section{Publisher's Note}

Springer Nature remains neutral with regard to jurisdictional claims in published maps and institutional affiliations.
Ready to submit your research? Choose BMC and benefit from:

- fast, convenient online submission

- thorough peer review by experienced researchers in your field

- rapid publication on acceptance

- support for research data, including large and complex data types

- gold Open Access which fosters wider collaboration and increased citations

- maximum visibility for your research: over $100 \mathrm{M}$ website views per year

At BMC, research is always in progress.

Learn more biomedcentral.com/submissions 